\title{
Product Life Cycle Planning
}

Jeffrey J. Walaszek, William D. Goran, Cary D. Butler, Kay C. McGuire, Terri L. Prickett, Kathleen D. White, and William J. Wolfe

\section{US Army Corps of Engineers $s_{\circledast}$ Engineer Research and Development Center}

\section{Technology Management Process}

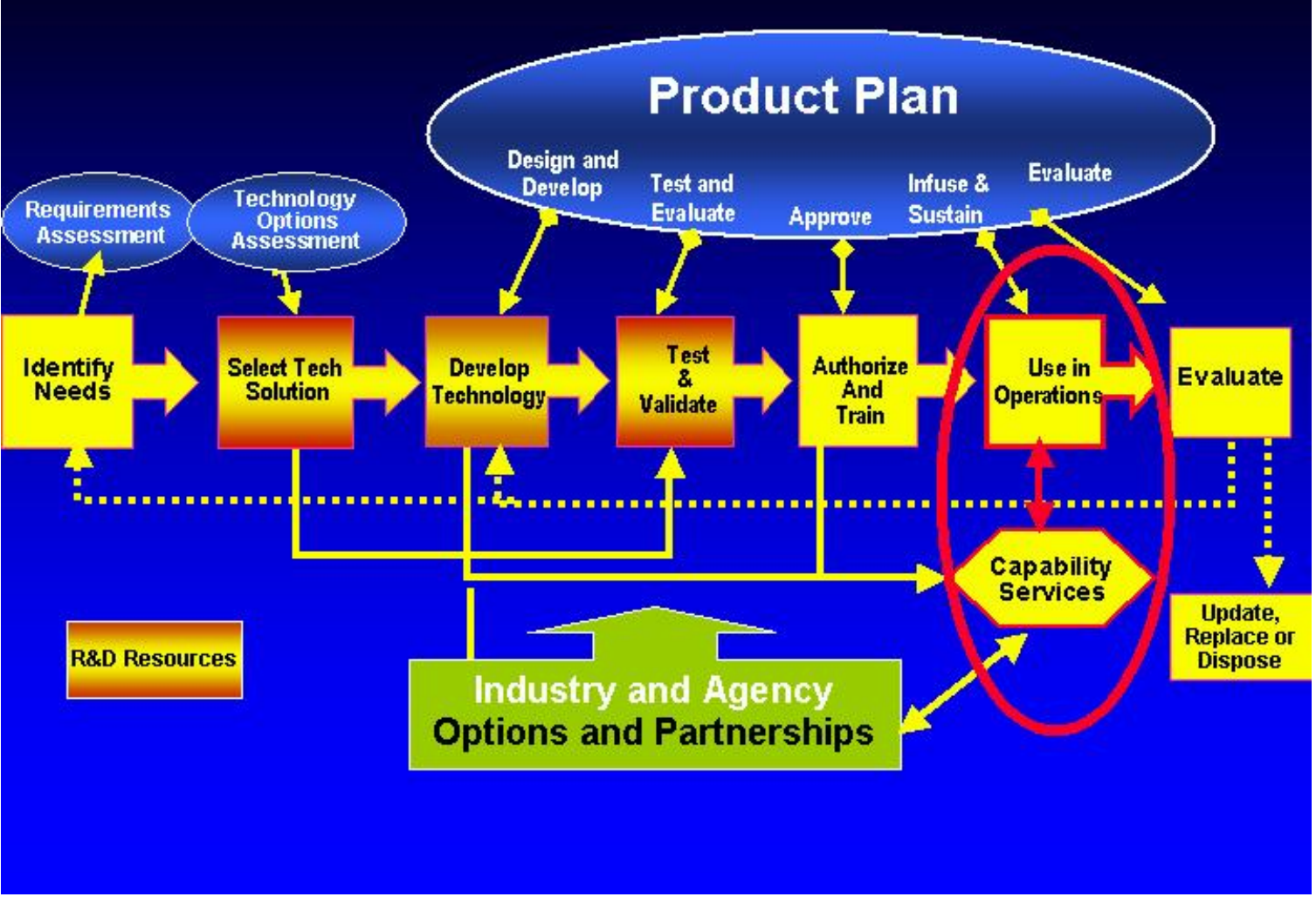




\section{Product Life Cycle Planning}

Cary D. Butler and William J. Wolfe

Information Technology Laboratory

William D. Goran and Kay C. McGuire

Construction Engineering Research Laboratory

Terri L. Prickett

Coastal and Hydraulics Laboratory

Jeffrey J. Walaszek

Headquarters, U.S. Army Engineer Research and Development Center

Kathleen D. White

Cold Regions Research and Engineering Laboratory

Final Report

Approved for public release; distribution is unlimited.

Prepared for U.S. Army Corps of Engineers

Washington, DC 20314-1000

Under

Work Unit \# RSM-E1 
Abstract: Regional Sediment Management (RSM) refers to the effective use of littoral, estuarine, and riverine sediment resources in an environmentally effective and economical manner. The U.S. Army Corps of Engineers manages lands and waterways across the United States. The Corps' use of RSM concepts will significantly improve the its mission accomplishment. As part of that mission, Corps' engineers and scientists develop new technologies to make management decisions more accurate and efficient. Simultaneously, they evaluate RSM concepts through demonstration projects that highlight and improve sediment management activities.

This phase of work was undertaken to: (1) provide guidelines, technical support, and planning approaches for researchers that result in realistic life cycle plans for products emerging from the RSM research program; (2) focus the RSM program community of interest on the planned outcomes of the RSM investment, and the infusion of these outcomes into District operations; (3) identify and resolve barriers to successful technology infusion; (4) develop approaches and metrics for measuring technology infusion success and processes for making post-infusion adjustments to improve this success, (5) facilitate successful technology transfer beyond USACE. The concepts proposed here are intended to improve life cycle planning from USACE research investments.

DISCLAIMER: The contents of this report are not to be used for advertising, publication, or promotional purposes. Citation of trade names does not constitute an official endorsement or approval of the use of such commercial products. All product names and trademarks cited are the property of their respective owners. The findings of this report are not to be construed as an official Department of the Army position unless so designated by other authorized documents.

DESTROY THIS REPORT WHEN IT IS NO LONGER NEEDED. DO NOT RETURN IT TO THE ORIGINATOR. 


\section{Contents}

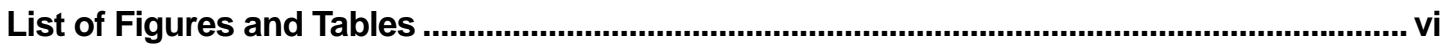

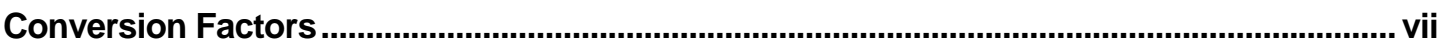

Preface

1 Introduction

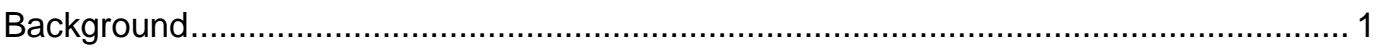

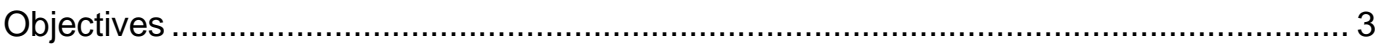

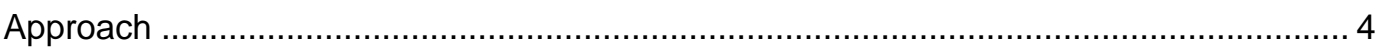

Scope

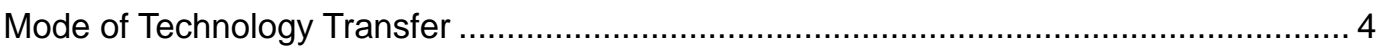

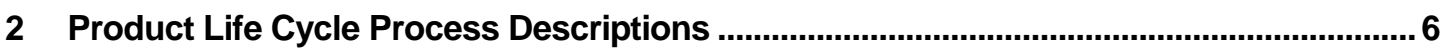

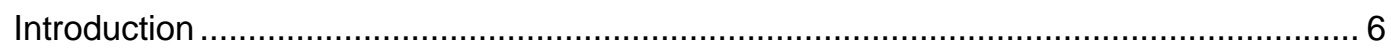

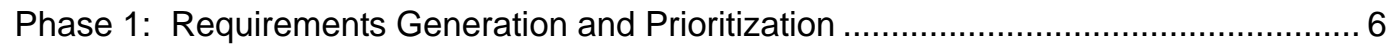

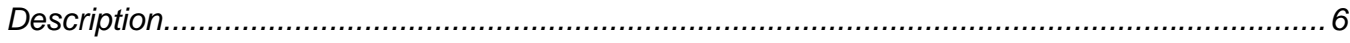

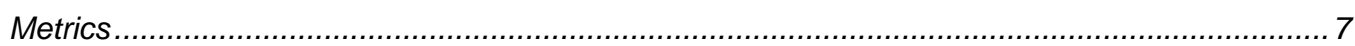

Phase 2: Assessment and Selection of Preferred Technology Solutions ......................... 8

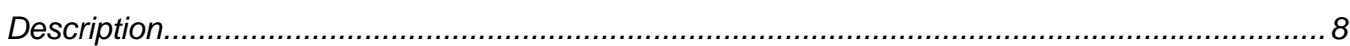

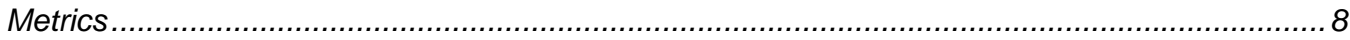

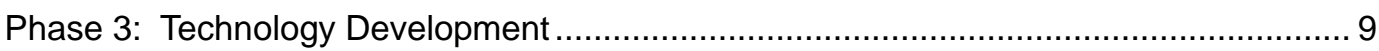

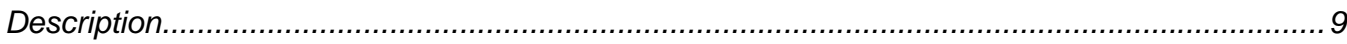

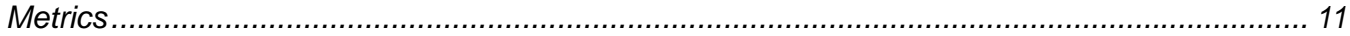

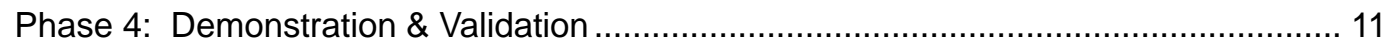

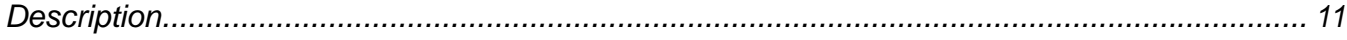

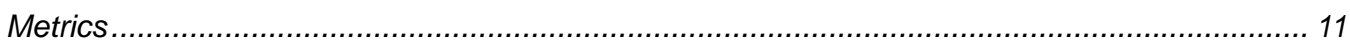

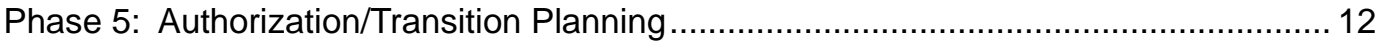

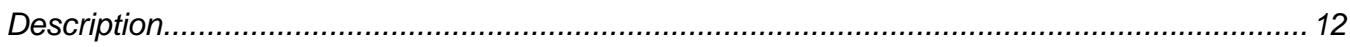

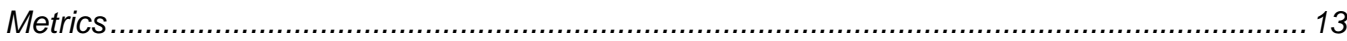

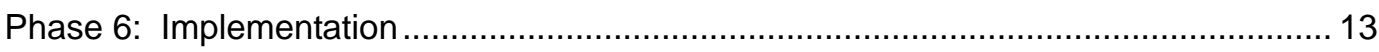

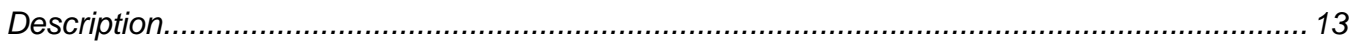

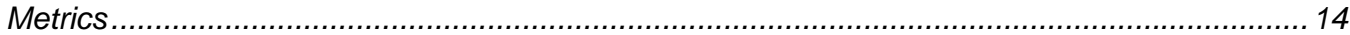

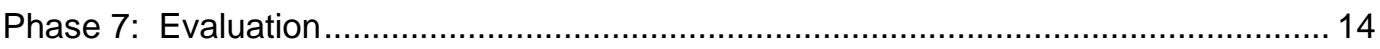

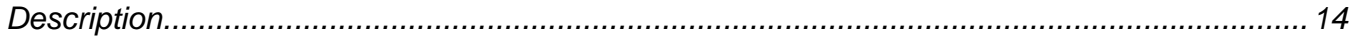

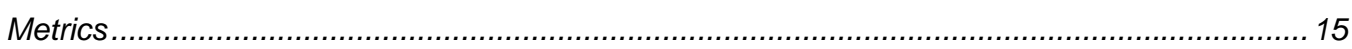


Phase 8: Technology Replacement / Reduction..................................................... 15

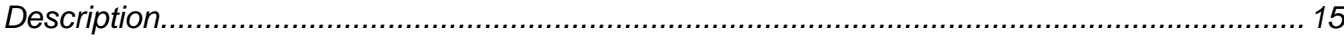

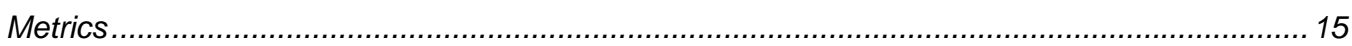

Project Delivery Teams and Product Life Cycle Planning …....................................... 16

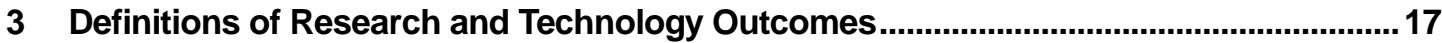

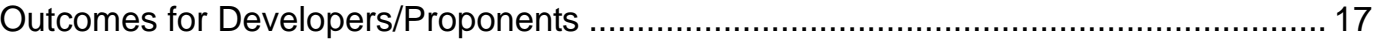

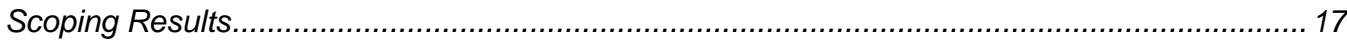

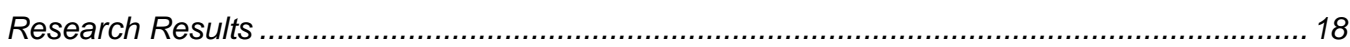

Outcomes for Users/Consumers (Products) ......................................................... 20

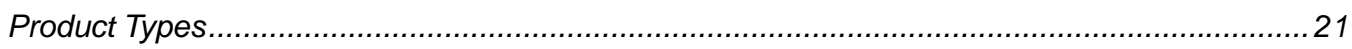

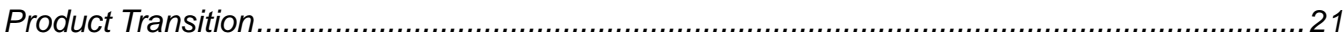

Example Preliminary Research Outcome Analysis for RSM ......................................... 23

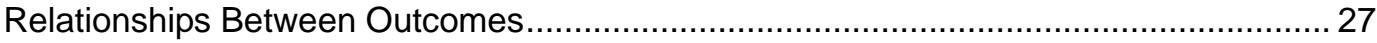

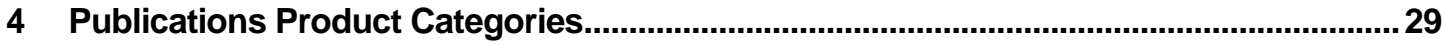

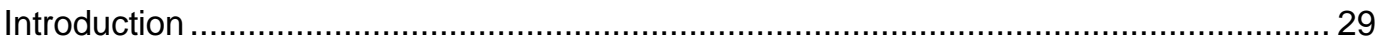

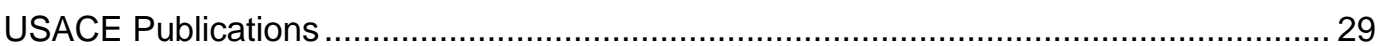

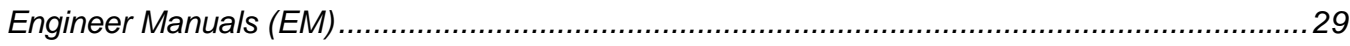

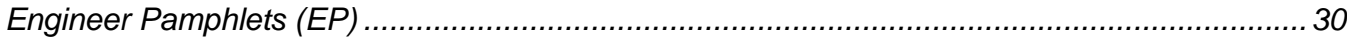

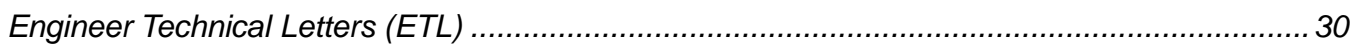

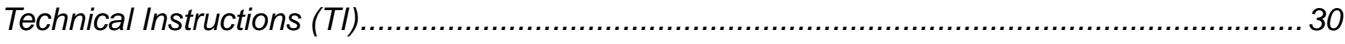

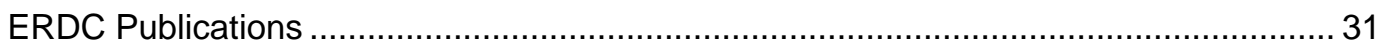

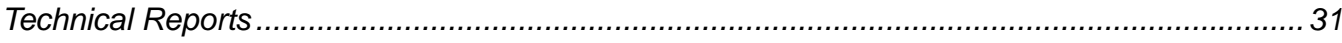

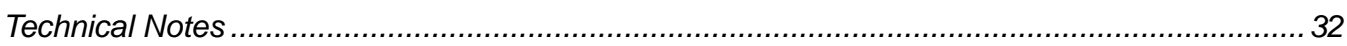

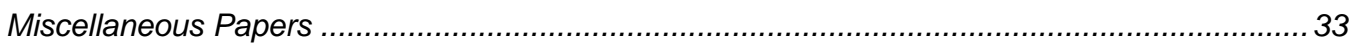

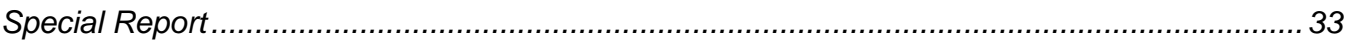

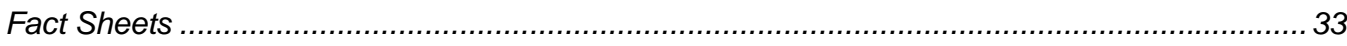

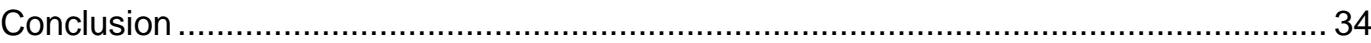

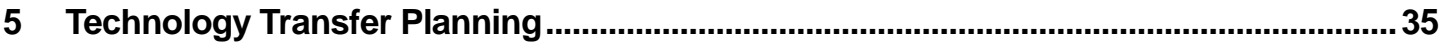

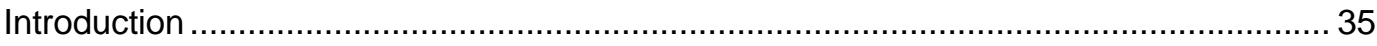

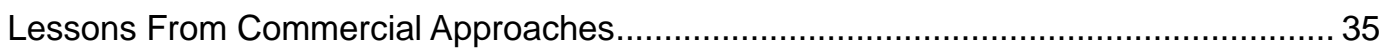

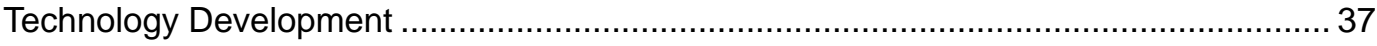

Identification of Future Operational Capabilities (FOC) and Requirements ...............................37

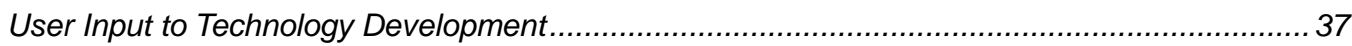

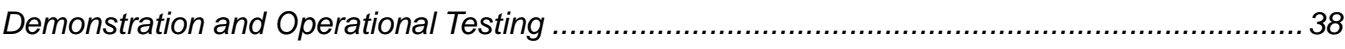

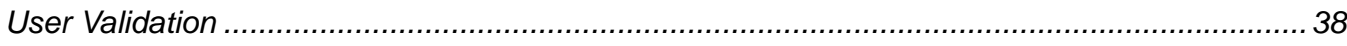

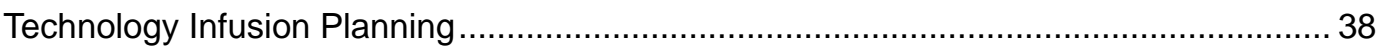

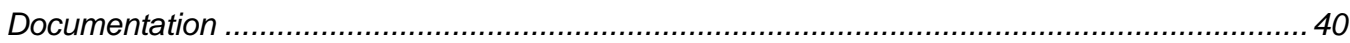

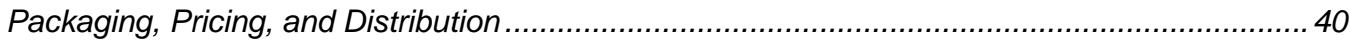

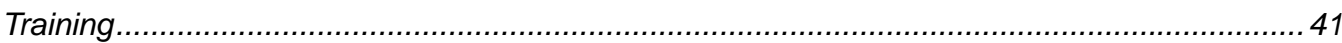




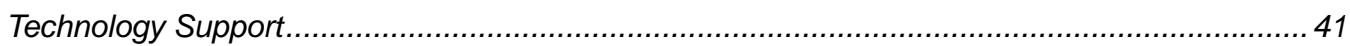

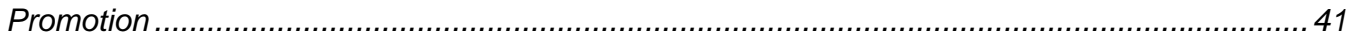

Preparing the Organization To Adopt a Technology ................................................ 42

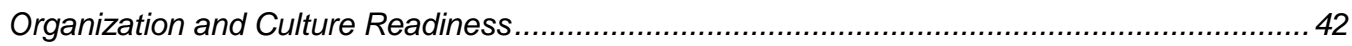

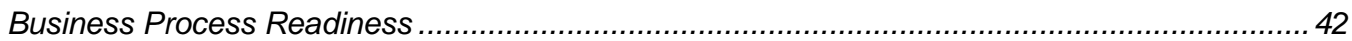

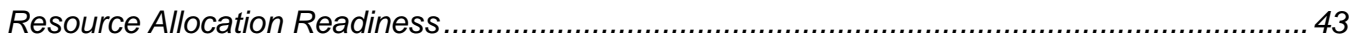

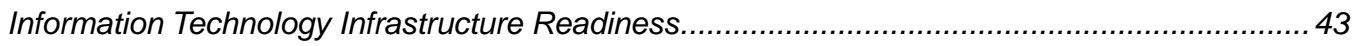

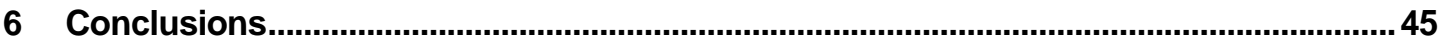

Bibliography

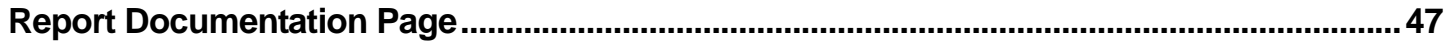




\section{List of Figures and Tables}

\section{Figures}

1 Roles and responsibilities pertaining to the product life-cycle process..................... 7

2 Guidance for further classification of research results and products ....................... 20

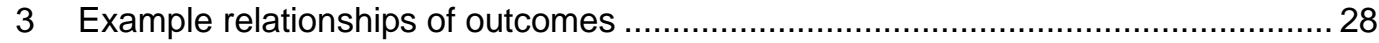

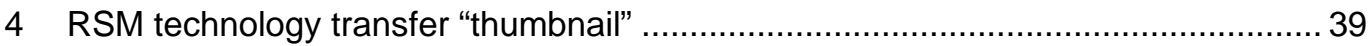

\section{Tables}

1 Participants and their responsibilities in the requirements generation process .......... 8

2 Participants and their responsibilities in the identification of technology

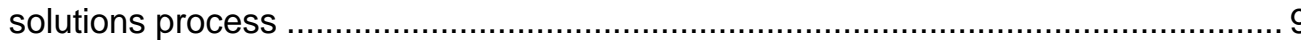

3 Participants and their responsibilities in technology development process .............. 10

4 Participants and their responsibilities in technology demonstration and

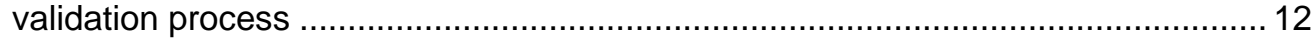

5 Participants and their responsibilities in authorization and transition planning

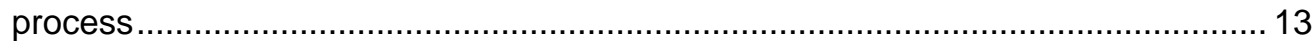

6 Participants and their responsibilities in implementation process............................ 14

7 Participants and their responsibilities in evaluation process ................................... 15

8 Participants and their responsibilities in disposal process ..................................... 16

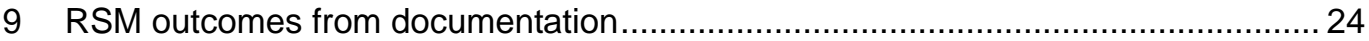

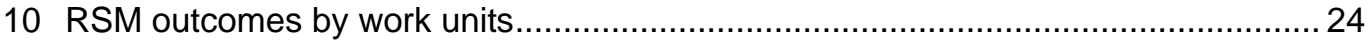

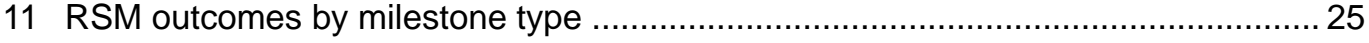

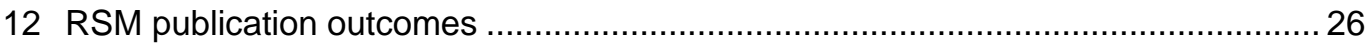




\section{Conversion Factors}

Non-SI* units of measurement used in this report can be converted to SI units as follows:

\begin{tabular}{|c|c|c|}
\hline Multiply & By & To Obtain \\
\hline acres & $4,046.873$ & square meters \\
\hline cubic feet & 0.02831685 & cubic meters \\
\hline cubic inches & 0.00001638706 & cubic meters \\
\hline degrees (angle) & 0.01745329 & radians \\
\hline degrees Fahrenheit & $(5 / 9) \times\left({ }^{\circ} \mathrm{F}-32\right)$ & degrees Celsius \\
\hline degrees Fahrenheit & $(5 / 9) \times\left({ }^{\circ} \mathrm{F}-32\right)+273.15$ & kelvins \\
\hline feet & 0.3048 & meters \\
\hline gallons (U.S. liquid) & 0.003785412 & cubic meters \\
\hline horsepower (550 ft-lb force per second) & 745.6999 & watts \\
\hline inches & 0.0254 & meters \\
\hline kips per square foot & 47.88026 & kilopascals \\
\hline kips per square inch & 6.894757 & megapascals \\
\hline miles (U.S. statute) & 1.609347 & kilometers \\
\hline pounds (force) & 4.448222 & newtons \\
\hline pounds (force) per square inch & 0.006894757 & megapascals \\
\hline pounds (mass) & 0.4535924 & kilograms \\
\hline square feet & 0.09290304 & square meters \\
\hline square miles & $2,589,998$ & square meters \\
\hline tons (force) & $8,896.443$ & newtons \\
\hline tons ( 2,000 pounds, mass) & 907.1847 & kilograms \\
\hline yards & 0.9144 & meters \\
\hline
\end{tabular}

\footnotetext{
*Système International d'Unités (“International System of Measurement”), commonly known as the "metric system."
} 


\section{Preface}

This study was conducted for Headquarters, U.S. Army Corps of Engineers (USACE) under Civil Works Project 392, Regional Sediment Management Research Program, Work Unit No. RSM-E1, "Product Life Cycle Planning." The original technical monitor for this project was William McAnally; the technical monitor at the completion of this work was Jack Davis, CEERD-HC-SE.

The work was performed by a team of investigators from several different USACE research organizations. William D. Goran of the Construction Engineering Research Laboratory (CERL) was the principal investigator. ERDC coauthors include: Cary D. Butler, Information Technology Laboratory (ITL); Kay C. McGuire (CERL); Terri L. Prickett, Coastal and Hydraulics Laboratory (CHL), Jeffrey J. Walaszek, Headquarters, U.S. Army Engineer Research and Development Center (ERDC); and Kathleen D. White, Cold Regions Research and Engineering Laboratory (CRREL). The technical editor, William J. Wolfe, ITL (Champaign site), also participated as a member of the research team. The Director of CERL is Dr. Alan Moore.

CERL, CHL, CRREL, and ITL are elements of the U.S. Army Engineer Research and Development Center (ERDC), U.S. Army Corps of Engineers. The Commander and Executive Director of ERDC is COL John Morris III, EN and the Director of ERDC is Dr. James R. Houston.

DISCLAIMER: The contents of this report are not to be used for advertising, publication, or promotional purposes. Citation of trade names does not constitute an official endorsement or approval of the use of such commercial products. All product names and trademarks cited are the property of their respective owners. The findings of this report are not to be construed as an official Department of the Army position unless so designated by other authorized documents.

DESTROY THIS REPORT WHEN IT IS NO LONGER NEEDED. DO NOT RETURN IT TO THE ORIGINATOR. 


\section{Introduction}

\section{Background}

Regional Sediment Management (RSM) refers to the effective use of littoral, estuarine, and riverine sediment resources in an environmentally effective and economical manner. RSM strives to maintain or enhance the natural exchange of sediment within the boundaries of the physical system. RSM changes the focus of engineering activities within the coastal, estuarine, and riverine systems from the local, or project-specific scale, to a broader scale that is defined by the natural sediment processes and that may include the entire watershed.

Implementation of RSM recognizes that the physical system and embedded ecosystems are modified and respond beyond the formal dimensions and time frames of individual projects. As a management method, RSM:

- includes the entire environment, from the watershed to the sea

- accounts for the effect of human activities on sediment erosion as well as its transport in streams, lakes, bays, and oceans

- protects and enhances the nation's natural resources while balancing national security and economic needs.

RSM's larger spatial and longer temporal perspectives, combined with the broad range of disciplines with a stake in RSM projects, require partnerships with and co-leadership of RSM initiatives by the stakeholders. Decisions concerning the timing and scope of projects that move or utilize sediment must be made within an understanding of the regional system.

The U.S. Army Corps of Engineers (USACE) holds in trust and manages lands and waterways across the United States. The Corps' use of RSM concepts will significantly improve the its mission accomplishment. As part of that mission, Corps' engineers and scientists develop new technologies through research to make management decisions more accurate and efficient. Simultaneously, they evaluate RSM concepts through demonstration projects that highlight and improve sediment management activities. 
Additionally, The U.S. Army Corps of Engineers uses Engineer Regulation (ER) 5-1-11* as its business process guide. This ER, which establishes philosophy, policy, and guidelines to accomplish all work performed by the U.S. Army Corps of Engineers, defines the Project Management Business Process (PMBP) as:

The fundamental USACE business process used to deliver quality projects. It reflects the USACE corporate commitment to provide "customer service" that is inclusive, seamless, flexible, effective, and efficient. It embodies communication, leadership, systematic and coordinated management, teamwork, partnering, effective balancing of competing demands, and primary accountability for the life cycle of a project. (p A2)

The regulation also stipulates seven imperatives that govern the PMBP (p 2):

\section{ER 5-1-11 USACE Business Process Imperatives}

1. One project, one team, one project manager

2. Plan for success and keep commitments

3. The Project Delivery Team (PDT) is responsible for project success

4. Measure quality with the goals and expectations in the Project Management Plan (PBP)

5. Manage all work with the PMBP, using corporate automated information systems (AIS's)

6. Build effective communications into all activities and processes

7. Use best practices and seek continuous improvement

The RSM Program, a new (begun FY02) Civil Works research initiative focused on providing understanding and solutions for regional management of sediment, is one of the three recent strategic Civil Works R\&D initiatives. Together with Technologies and Operational Innovations for Urban Watershed Networks (TOWNS), and the System-Wide Modeling, Assessment, and Restoration Technologies (SMART) program, the RSM Program is breaking new ground in program development and execution.

RSM Program sponsors, proponents, program managers, field advisors, and investigators are all jointly concerned that the outcomes from this research program provide value to the agency and to others. To ensure this successful outcome, all research programs need to address product life-cycle planning. This

\footnotetext{
* ER 5-1-11, U.S. Army Corps of Engineers Business Process Headquarters (Headquarters, U.S. Army Corps of Engineers [HQUSACE], Washington, DC, 17 August 2001).
} 
work was undertaken to fill that program-development need, to addresses product milestone descriptions and definitions of research outcomes for use in life cycle planning, and to provide direction on publications and technology transfer planning.

\section{Objectives}

Overall objectives of the RSM Program * are to:

1. Provide necessary knowledge and enabling technologies that will lead to improved capabilities for regional sediment management.

2. Provide analytical techniques and models that give the USACE the capability to characterize both regional-scale and local-scale project sediment impactssediment yield, transport and fate-and to evaluate management alternatives.

3. Provide guidance for designing, constructing, operating, and maintaining water resource projects to effectively manage sediment from a regional perspective and to manage individual projects within the context of regional sediment management objectives.

4. Produce an information and knowledge (informatics) complete with data, software tools, and procedures that facilitate effective Corps business practices and decisionmaking in regional sediment management.

5. Rapidly and effectively transfer the products from this program to Corps of Engineers personnel, insert its tools into Corps' practices, inform and be informed by stakeholders, and facilitate mutually beneficial exchanges with other organizations.

Specific objectives for this phase of work were to:

1. Provide guidelines, technical support, and planning approaches for researchers that result in realistic and valuable life cycle plans for products emerging from the RSM and other related research programs.

2. Focus the RSM program community of interest (program manager, field advisors, proponents, collaborators, investigators) on the planned outcomes of the RSM investment, and the issues associated with successful infusion of these outcomes into District operations.

3. Identify and resolve barriers associated with successful technology infusion.

\footnotetext{
*Regional Sediment Management Research Program (July 2002, William McAnally).
} 
4. Develop approaches and metrics for measuring technology infusion success and processes for making post-infusion adjustments to improve this success.

5. Facilitate successful technology transfer beyond USACE.

\section{Approach}

The planning effort involved coordination of a "virtual committee," which:

1. Identified the nature and type of planned outcomes from the RSM research program.

2. Developed guidelines to move planned products through a cycle of consistent steps necessary for successful technology infusion. This involved developing the necessary resources and procedures to facilitate life cycle planning, including:

a. A product/milestones database for RSM

b. Publication templates for RSM

c. Post-infusion metrics and analysis tools

d. A framework for learning lessons from RSM experiments and applications.

3. Coordinated these guidelines with RSM investigators, proponents, field advisors and other stakeholders.

4. Outlined steps to ensure that these guidelines reach the intended investigators through presentations, workshops, reviews, web services and other mechanisms and forums.

\section{Scope}

This Product Life Cycle Planning effort is focused primarily on the technological outcomes that will emerge from the Regional Sediment Management Research Program. However, this investment in life cycle planning will directly inform approaches for two other new Civil Works research programs: System-wide Modeling, Assessment, and Restoration Technologies (SMART), and Technologies and Operational Innovations for Urban Watershed Networks (TOWNS). In addition, this life cycle planning approach will help inform all other military and civil research programs conducted by USACE research organizations.

\section{Mode of Technology Transfer}

The primary focus of life cycle management of RSM outcomes is to facilitate successful technology infusion of these outcomes into operational approaches across the Corps of Engineer Districts. Another important objective for life cycle plan- 
ning is to achieve successful transfer of technology outcomes to the scientific community and to organizations that partner with or work independently from the Corps of Engineers.

It is anticipated that the outcomes of the RSM Program (numerous reports, databases, models or model enhancements, workshops, guidelines and other outcomes related to Program objectives) will be disseminated through published guidelines, workshops, web services, and specific tools and procedures that will be delivered directly to RSM investigators and other RSM stakeholders. This report will be made accessible through the World Wide Web (WWW) at URL:

http://www.cecer.army.mil 


\section{Product Life Cycle Process Descriptions}

\section{Introduction}

An understanding of the research, development, and technology transfer process is critical for those organizations and individuals involved in the process. The ultimate goal of the process is to develop and field technology that enables the Army customer to conduct business in the most efficient manner. This chapter describes the various stages of the technology life-cycle management process and identifies the responsibilities for the various organizations involved in the process. The process (shown in Figure 1) consists of these phases:

- Requirements generation and prioritization

- Assessment and selection of preferred technology solutions

- Technology development

- Demonstration and validation

- Authorization/transition planning

- Implementation

- Technology evaluation

- Disposal.

\section{Phase 1: Requirements Generation and Prioritization}

\section{Description}

The Product Life Cycle Process begins with the identification of critical problems to be solved through research activities. The objective of the first phase of product life cycle planning is to identify a prioritized listing of problems and needs that can be developed into requirements documents for use in defining the research and development activities and the overall technology management effort.

Problems and needs can come from personnel at Headquarters, Major Army Commands, laboratories, Corps Divisions and Districts, and installations and other users. Technology proponents at headquarters can work with field review and advisory groups to review submitted problems and need statements and prioritize those as most important to the Army at large. 


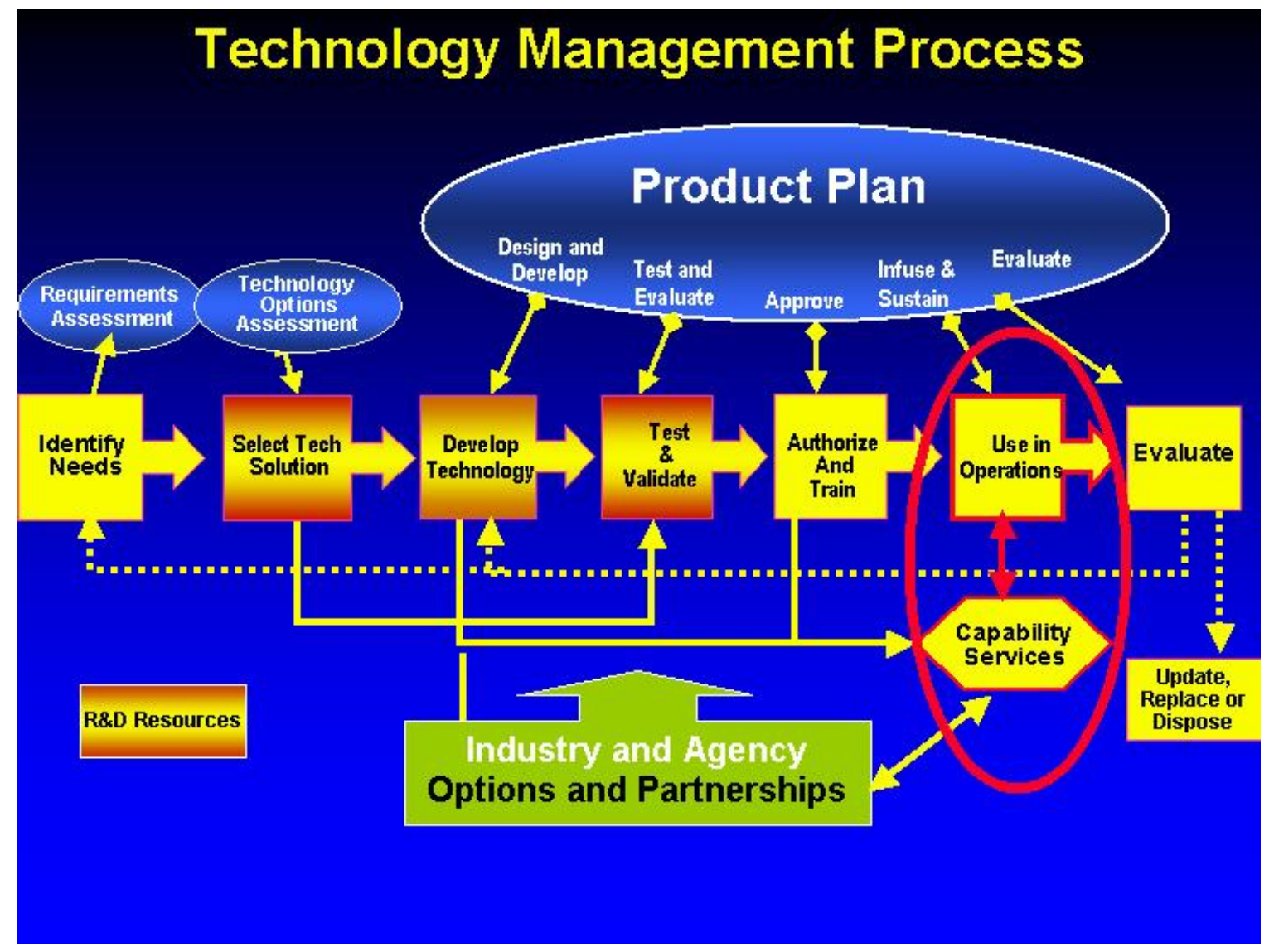

Figure 1. Roles and responsibilities pertaining to the product life-cycle process.

These needs should be considered in conjunction with broader Army and organizational objectives. These identified and prioritized needs should be written up in a formal requirements document. Technology developers use these requirements documents to develop the research and development program. In some cases, the R\&D community may conduct a more detailed requirements analysis to further define these requirements. These requirements documents should be reviewed and updated annually by the proponents working with the representatives of field organizations (field review groups). Table 1 lists the participants in the requirements generation process and their responsibilities.

\section{Metrics}

- Requirements documents have been revised or developed based on an updated listing of prioritized critical needs.

- Authorization is granted to investigate the means and feasibility of resolving the need. 
Table 1. Participants and their responsibilities in the requirements generation process.

\begin{tabular}{|c|c|}
\hline Participant & Responsibilities \\
\hline Proponents & $\begin{array}{l}\text { - Provide a top-down perspective on future technology requirements based on Army and } \\
\text { organizational goals and strategies } \\
\text { - Regularly solicit input from end users on critical and long term problems } \\
\text { - Conduct meeting of field review groups to identify and prioritize research needs } \\
\text { - Use input from field review groups to develop requirements documents }\end{array}$ \\
\hline Developers & $\begin{array}{l}\text { - Collect information on user needs for use in developing R\&D program } \\
\text { - Provide input to field review groups on needs based on their contact with users } \\
\text { - Assist proponents in development and documentation of requirements }\end{array}$ \\
\hline Users & $\begin{array}{l}\text { - Assign individuals to serve as technical representatives on field review groups } \\
\text { - Provide input on research needs to proponents and field review groups }\end{array}$ \\
\hline
\end{tabular}

\section{Phase 2: Assessment and Selection of Preferred Technology Solutions}

\section{Description}

The objectives of the second phase of product life cycle planning are to: (1) develop and conduct a research program addressing the critical needs identified in requirements documents, and (2) assist developers and proponents identify the proposed optimal solution to the need or problem. This phase typically starts with some type of technology options analysis. During this analysis, commercial technology also should be considered. Information provided by vendors can be reviewed to determine the benefits and uniqueness of the technology. In this phase, individual research efforts are established to identify technical solutions to problems identified in the requirements documents. Proponents and occasionally field review groups will provide input to the research effort to assist the developers in assessing the merits of alternatives being considered. This phase results in an optimal solution to the identified need that has undergone a proof of concept test or is generally recognized by developers and proponents to be an optimal solution. The proposed solution will be technically feasible. Table 2 lists the participants in the identification of technology solutions and their responsibilities.

\section{Metrics}

- Alternative solutions that satisfy the need were considered. The organization via the proponents is committed to implement the proposed solution and incorporate it into its operations. 
Table 2. Participants and their responsibilities in the identification of technology solutions process.

\begin{tabular}{|l|l|}
\hline Participant & Responsibilities \\
\hline Proponents & $\begin{array}{l}\text { - Conduct meeting of field review groups to provide input on proposed technology } \\
\text { solutions developed by laboratories }\end{array}$ \\
& $\begin{array}{l}\text { - Provide input on proposed technology solutions } \\
\text { - Define business practices and the user environment in which the technology solution } \\
\text { would be applied }\end{array}$ \\
\hline - Provide initial commitment to support the transfer and fielding of proposed technology \\
solution
\end{tabular}

\section{Phase 3: Technology Development}

\section{Description}

Once the optimal solution has been identified, developers will focus their efforts on developing the technology. The objectives of the technology development phase of product life cycle planning are to: (1) develop a technology solution that is technically workable as proven via field testing and (2) develop a draft technology infusion plan addressing all aspects of implementation activities including funding. If a commercial technology is chosen as the solution to the stated requirement, this phase may be bypassed. Developers and proponents will ensure the technology will be interoperable with existing legacy systems and new systems in development. Developers will work with proponents and users to ensure the solution will fit within existing business practices or make plans to adjust business practices based on the technology solution. Special emphasis should be directed towards how the technology will be applied by potential users. Draft versions of user manuals or some form of user training aids will need to be 
developed to assist users during pilot tests and demonstrations. At this point, initial product life cycle plans will be developed addressing technology transfer and all aspects of product life cycle management. These plans will be finalized later in the authorization and transition planning phase.

Some technology solutions may be complicated or require specialized expertise to run such as in the case of some models. These solutions may be best implemented not as a product transferred to all users, but as a capability or service provided by a limited number of providers. These providers can then staff up and train a workforce to specialize in providing that technology solution to users.

Specialized user groups or project delivery teams (PDTs) can be established to provide input in the development of the technology, the system-user interface, related business processes, initial training materials, and technology infusion plans. Alpha tests will be conducted to ensure the technical adequacy of the technology. Table 3 lists the participants in the technology development phase of life cycle planning and their responsibilities.

Table 3. Participants and their responsibilities in technology development process.

\begin{tabular}{|c|c|}
\hline Participant & Responsibilities \\
\hline Proponents & $\begin{array}{l}\text { - Participate in project delivery teams (PDTs) as appropriate } \\
\text { - Provide input/decisions on business practices that will be affected or need to be } \\
\text { modified based on the implementation of the technology } \\
\text { - Oversee the development of proposed initial technology transfer plan covering all } \\
\text { aspects of the implementation activities }\end{array}$ \\
\hline Developers & $\begin{array}{l}\text { - Conduct developmental research to create the technology solution } \\
\text { - Ensure the technology is compatible with existing or future Army operations } \\
\text { - Conduct user groups or solicit field input as appropriate to guide the development } \\
\text { of the technology with particular emphasis on the system-user interface and } \\
\text { accompanying business Practices } \\
\text { - Assist proponent in development of proposed technology transfer plan } \\
\text { - Develop draft instructional documents to assist the user in applying the technology } \\
\text { - Conduct alpha tests of the developed technology and draft instructional } \\
\text { documents to ensure their technical adequacy }\end{array}$ \\
\hline Users & $\begin{array}{l}\text { - Participate in user groups or other forums to provide input to the technology } \\
\text { development effort } \\
\text { - Provide input on field operations and business practices to support the technology } \\
\text { development } \\
\text { - Provide input on system-user interface to help define the "look and feel" of the } \\
\text { product } \\
\text { - Provide input to the proposed technology transfer plan }\end{array}$ \\
\hline
\end{tabular}




\section{Metrics}

- Authorization is granted to execute a project plan that produces products for a product suite and resolves the recognized need. (LP02, LCMIS II)

- All components of the project are designed. The design supports the user's published technology policy/requirements.

- The operational products are designed to interoperate with other technologies in use in the user's environment.

- A product prototype was tested in a controlled environment without identifying any critical deficiency in the prototype. This is the successful completion of an alpha test.

- A product prototype was successfully tested in an environment emulating the user's environment. The technology is now ready for demonstration/beta testing.

\section{Phase 4: Demonstration \& Validation}

\section{Description}

The field demonstration/beta test is a key element in the overall transfer of the technology. The objective of this phase of product life cycle planning is to demonstrate the application of the technology in a real life setting to document its cost effectiveness and determine operational difficulties encountered by users. The demonstration/beta test is the first attempt to show the effectiveness of the technology to users. Unlike the proof of concept and alpha tests, which are intended to test and refine the technology, the demonstration/beta test focuses on how the user implements and benefits from the technology. A successful demonstration/beta test will produce information on cost of implementation, savings achieved from its use, and operational problems facing users resulting from its implementation and use.

The demonstration also provides an opportunity to identify the effectiveness of instructional materials. Table 4 lists the participants in the technology demonstration and validation phase of product life cycle planning and their responsibilities.

\section{Metrics}

- The product has completed testing in the user's environment for successful completion of the beta test.

- The product performs adequately in the user's environment and is ready for operation in the user's operating offices. 
Table 4. Participants and their responsibilities in technology demonstration and validation process.

\begin{tabular}{|l|l|}
\hline \multicolumn{1}{|c|}{ Participant } & Responsibilities \\
\hline Proponents & $\begin{array}{l}\text { - Actively seek out funding or opportunities to demonstrate/beta tests as part of existing } \\
\text { projects }\end{array}$ \\
& $\begin{array}{l}\text { - Provide input to demonstration site selection } \\
\text { - Monitor results of demonstrations and make decision on readiness of the technology for } \\
\text { implementation }\end{array}$ \\
\hline Developers & $\begin{array}{l}\text { - Develop appropriate contractual clauses or specifications unique to the technology to } \\
\text { assist site personnel procure and apply the technology at the demonstration site }\end{array}$ \\
& $\begin{array}{l}\text { - Conduct demonstrations or assist in applying technologies } \\
\text { - Document the results of the demonstration with an emphasis on costs and benefits } \\
\text { transfer }\end{array}$ \\
\hline Users & $\begin{array}{l}\text { - Provide input and assist proponents and developers in lining up demonstration sites } \\
\text { - Implement the technology at demonstration sites with assistance from developers } \\
\text { - Assist developers in documenting benefits, costs, and operational issues during the }\end{array}$ \\
\hline
\end{tabular}

\section{Phase 5: Authorization/Transition Planning}

\section{Description}

Following the successful completion of the demonstration, technology proponent groups will work with headquarters personnel to identify and authorize technologies for use by the Army. The objectives of this phase of product life cycle planning are to finalize the technology transfer plan, including the various implementation activities, obtain the Army commitment, authorization, and funding necessary to implement the technology and the technology infusion plan, and mobilize personnel and resources to implement the technology infusion plan. The technology transfer plan will cover all aspects of the implementation planning activities-promotion, packaging and distribution, training, user support, and funding. Responsibilities for carrying out the various elements of the technology transfer plan will be assigned with appropriate funding and organizational support as needed. Participants may include developers, user-based centers of expertise, and industry and academic organizations. Interim guidance and criteria documents will be prepared to authorize use of the technology while formal documents are being updated. Table 5 lists the participants and their responsibilities in the authorization and transition planning phase of product life cycle planning. 


\section{Metrics}

- Implementation of a technology can occur once the various components of the implementation mix are in place and resourced.

- Organizations having responsibility in implementation must be ready to actively assume and implement those responsibilities.

\section{Phase 6: Implementation}

\section{Description}

During this phase, the technology transfer plan is put into place. The objective of this stage of product life cycle planning is to distribute and encourage the use of the technology Army-wide, and to provide follow-up support to users. Organizations supporting each of the elements in the technology transfer plan are carrying out their duties in support of users implementing the technology. Evaluations of the technology and the various elements of the technology transfer plan are conducted regularly to monitor progress. Critical to the success of any technology transfer plan are the provisions for training and support to users. Table 6 lists the participants and their responsibilities in the implementation phase of product life cycle planning.

Table 5. Participants and their responsibilities in authorization and transition planning process.

\begin{tabular}{|c|c|}
\hline Participant & Responsibilities \\
\hline Proponents & $\begin{array}{l}\text { - Finalize technology infusion plan that covers all aspects of the implementation planning } \\
\text { activities } \\
\text { - Identify and oversee the revision of Army technical documents to reflect technology } \\
\text { - Assign responsibilities and monitor actions for carrying out the various components of the } \\
\text { technology infusion plan } \\
\text { - Identify sources of funding to support development of technology transfer plans and later } \\
\text { implementation activities }\end{array}$ \\
\hline Developers & $\begin{array}{l}\text { - Develop appropriate contractual clauses to assist users in obtaining technology } \\
\text { - Assist proponents in developing and carrying out activities within the technology infusion } \\
\text { plans } \\
\text { - Develop input to revisions of Army technical documents under direction of proponents }\end{array}$ \\
\hline Users & $\begin{array}{l}\text { - Participate in field review groups to provide input to the technology infusion plans } \\
\text { - Serve as champions to encourage the use of the technology within their organizations } \\
\text { - Identify funding sources and mechanisms within organizations to support technology } \\
\text { transfer }\end{array}$ \\
\hline
\end{tabular}


Table 6. Participants and their responsibilities in implementation process.

\begin{tabular}{|l|l|}
\hline \multicolumn{1}{|c|}{ Participant } & Responsibilities \\
\hline Proponents & $\begin{array}{l}\text { - Oversee the implementation of the technology and the activities of the various } \\
\text { organizations involved in implementing elements of the technology transfer plan } \\
\text { - Ensure that interim technical guidance is eventually replaced by the revision of more } \\
\text { formal Army technical documents } \\
\text { - Coordinate technology transfer implementation activities among } \\
\text { USACE/Army/contractor organizations } \\
\text { - Ensure technology transfer activities are adequately funded }\end{array}$ \\
\hline Developers & $\begin{array}{l}\text { - Assist the proponents and designated technology support agents in assisting users as } \\
\text { required by the technology transfer plan }\end{array}$ \\
& $\begin{array}{l}\text { - Implement technical support, training, promotional efforts supporting field use of the } \\
\text { technology }\end{array}$ \\
\hline Users & Become a champion for local implementation of the technology transfer plan \\
&
\end{tabular}

\section{Metrics}

- The product has been infused successfully into all the user's locations.

- The product is in routine use in support of user business operations.

\section{Phase 7: Evaluation}

\section{Description}

The objective of this phase of product life cycle planning is to identify needed improvements in the technology and support activities via periodic assessments of technology use and support activities. Evaluations of the success of the technology and technology transfer plan over the long term may result in further modifications to the technology and technology transfer strategies. The technology may once again go through some or all phases of the product life-cycle technology management process. (The red arrow in Figure 1 [p7] shows how the evaluation activity may conceptually lead back to Phase 1.) Evaluations may also identify deficiencies in existing support activities or documentation that need to be addressed. Input from these evaluations may lead to new technology requirements that will result in the current technology being replaced. Furthermore, an evaluation may lead to a recommendation to eliminate a technology, for example, if the technology has become obsolete, if it is no longer cost effective to maintain the technology, or if the function it supports is no longer required. Table 7 lists the participants and their responsibilities in the evaluation phase of product life cycle planning. 
Table 7. Participants and their responsibilities in evaluation process.

\begin{tabular}{|l|l|}
\hline \multicolumn{1}{|c|}{ Participant } & Responsibilities \\
\hline Proponents & $\begin{array}{l}\text { - Provide oversight to technology support activities to ensure they are effectively } \\
\text { supporting the use of the technology in the field } \\
\text { - Periodically monitor use of the technology to evaluate long-term success of the various } \\
\text { elements of the technology transfer plan and modify the activities as appropriate } \\
\text { - Obtain input from the field via user groups or other evaluation techniques }\end{array}$ \\
\hline Developers & $\begin{array}{l}\text { - Periodically gather feedback for proponent on the effectiveness of the technology } \\
\text { - Monitor use of the technology and user inquiries to identify problems with field use of } \\
\text { the technology and to propose future modifications }\end{array}$ \\
\hline Users & $\begin{array}{l}\text { - Evaluate effectiveness of promotional materials, training efforts, and other user } \\
\text { documents and make recommendations to modify as needed }\end{array}$ \\
& technology transfer activities
\end{tabular}

\section{Metrics}

- The product may require changes to maintain operation capability. Changes may be due to changes in technology, policy, business process or law.

- The product is no longer needed in the user's environment and needs to be removed from the operational architecture.

\section{Phase 8: Technology Replacement / Reduction}

\section{Description}

Products at some point will need to be replaced by new or alternate technologies. The objective of this stage of product life cycle planning is to efficiently remove the product from use with minimal impact on existing business processes and operations. The disposal process includes the decision to dispose of the product, transition it from the software inventory, and business practices to operate without it or to operate with its replacement. Table 8 lists the participants and their responsibilities in the disposal phase of product life cycle planning.

\section{Metrics}

- The product's replacement is identified and the enterprise has committed to implementing the replacement product.

- The product has been removed from the operational environment. 
Table 8. Participants and their responsibilities in disposal process.

\begin{tabular}{|l|l|}
\hline \multicolumn{1}{|c|}{ Participant } & Responsibilities \\
\hline Proponents & $\begin{array}{l}\text { - Make decision to dispose of technology as a result of input on new technology } \\
\text { developments, availability of replacement products, etc. } \\
\text { - Develop a disposal strategy that minimizes impact on existing field operations }\end{array}$ \\
\hline Developers & $\begin{array}{l}\text { - Support disposal activities in support of proponent product disposal strategy } \\
\text { - Enable data conversions to new software }\end{array}$ \\
\hline Users & $\begin{array}{l}\text { - Enable continuity of operations for users during transition of new software } \\
\text { inventory }\end{array}$ \\
\hline
\end{tabular}

\section{Project Delivery Teams and Product Life Cycle Planning}

User input to the product life cycle planning process is critical to the successful transition of the product into use. Project Delivery Teams (PDTs) should be developed to develop the product plan for a preferred technology solution. The product plan includes the approach for product design and development; testing, evaluation, and approval; technology infusion; and the post-infusion analysis. Each PDT should consist of a representative mix of proponents, developers, and users. Each member will provide their unique perspective into the development and delivery of the preferred technology solution. The PDT will then assist the proponent in the eventual transfer of the technology into use.

This technology transfer requires a common terminology to define and describe the outcomes of each phase, and the preparations for the next phase. A common terminology will help to clarify the process to all its participants, through all the phases, and help to successfully transition the process "between phases." Chapter 3 defines and describes the terminology governing research outcomes, which will ultimately be used to formulate technology development and technology transfer plans. 


\section{Definitions of Research and Technology Outcomes}

"Outcomes" are categorized here as outcomes either for developers/proponent or for users/consumers. This information will be used in developing technology development plans and subsequent technology transfer plans. Consistent use of these terms will facilitate communication among technology proponents, end users, and other researchers. This Chapter defines and categorizes research outcomes or milestones from (as a working example) various RSM work units. The outcomes are categorized by who will use them and by how the various outcomes from each work unit will contribute to the ultimate product or capability provided to the end users.

\section{Outcomes for Developers/Proponents}

\section{Scoping Results}

\section{Requirements Assessment}

The purpose of requirements assessment is to clarify, magnify, and (if possible) quantify a requirement or opportunity. This requirements scoping is the most critical scoping effort because the outcomes of these efforts drive the R\&D investment strategies. The product of this effort is a report with recommendations (preferable with options) for future investments. Recommended R\&D investments could include meeting a specific product requirement, doing research to address specific unknown processes, gathering an existing knowledge base into some accessible/deliverable format, or creating a suite of investments that comprise an entire "program." The scoping work is conducted by senior R\&D and user representatives. This type of scoping effort is not primarily focused on detailed analysis of life cycle costs-rather it is focused on characterizing a requirement and considering multiple options and priorities to address this requirement. These scoping efforts should also consider life-cycle implications. Three important outcomes from these requirements assessment are: (1) a clear statement of the initial requirement, which has been reviewed by a team of users, technology developers, and proponents, (2) a "use case" statement that describes how the desired outcome from this requirement will be used, and (3) met- 
rics to measure the extent to which the desired outcomes meets the requirements objective (e.g., reduces cost or time for an operation, increases organizational capability, improves decisions, etc.).

\section{Technology Options Assessment}

A "Technology Options Analysis" is appropriate after a requirements scoping effort is complete. At this point multiple technology solutions might be considered to meet a requirement. This assessment will result in a decision regarding specific actions to undertake to achieve desired (and well described) research or product outcomes. Creative alternative solutions should keep a strong focus on the outcome and consider the life cycle implications of this outcome. This allows the developer to anticipate and plan various coordination issues as early as possible. At this stage of an effort, however, these is still risk and uncertainty, so this assessment should not "lock in" these resources; rather, it should create placeholders that get reviewed as the effort progresses. This approach scoping effort is primarily the responsibility of the tech developer/proposer, with involvement from the user proponent and representatives.

\section{Product Plan Development}

"Product Plan Development" is developing a detailed product life cycle plan for a preferred technology solution identified in the technology options assessment. The product plan includes the approach for product design and development; testing, evaluation, and approval; technology infusion; and the post-infusion assessment. At this point, uncertainty and risk in terms of the R\&D outcome should be minimal. The product plan goes well beyond the technology options assessment because it involves the transition from "placeholders" to "locked" scheduling and budgeting actions. All the issues associated with moving a technology into the field need to be detailed, risks need to be identified and addressed, and various infusion options must be considered. Budget and schedule constraints (or opportunities) may require adjustments to the plans approved as a result of the approach scoping recommendations. This scoping effort needs to be led by the proponents and users, with assistance from the tech developers.

\section{Research Results}

Research results are defined here as the outcomes of the research activities that contribute to the further expansion of scientific knowledge or the continuing development of a product or capability to be used by end users (Figure 3). The primary audience and user of research results are other researchers and developers who will use the outcomes to further enhance or develop a product or con- 
duct additional research. The non-research consumer will unlikely "touch and feel" a research result, although they may review and benefit from research knowledge disseminated via published information exchange efforts.

\section{Information Generation}

"Information generation" refers to the activities and investigations leading to a further understanding of scientific and engineering principles and processes. These include activities such as literature reviews, scientific symposia and workshops to solicit information, data collection in laboratory and field settings, and scientific and technical analyses.

\section{Component Development}

"Component development" is the production of some element that will contribute to the further development of the final product to be fielded to the actual user of the technology. A component could include an algorithm to be used in a model, a model concept or framework for development into a prototype model, end user visualization schema for the user interface to a program, or program code to speed the processing of information within a software program.

\section{Information Exchange}

"Information exchange" is defined as documenting and communicating the results of the research activities to other researchers and developers. Information exchange is conducted via research reports, articles in peer-reviewed journals, and papers presented at technical symposia attended by researchers.

\section{Process Milestone}

An interim step in the research and development process that contributes to the ultimate result of the research, but does not in itself generate knowledge or result in a component is defined as a "process milestone." This includes such activities as developing a survey instrument, letting a contract, constructing a physical model, or procuring instrumentation or software to support the research effort. Process milestones will occur under all outcome categories.

\section{Prototype}

A prototype is an initial version of the product or product enhancement. A prototype would be used by developers to more fully test, develop, and refine the technology concept. Users/consumers would not implement a prototype on their own. 


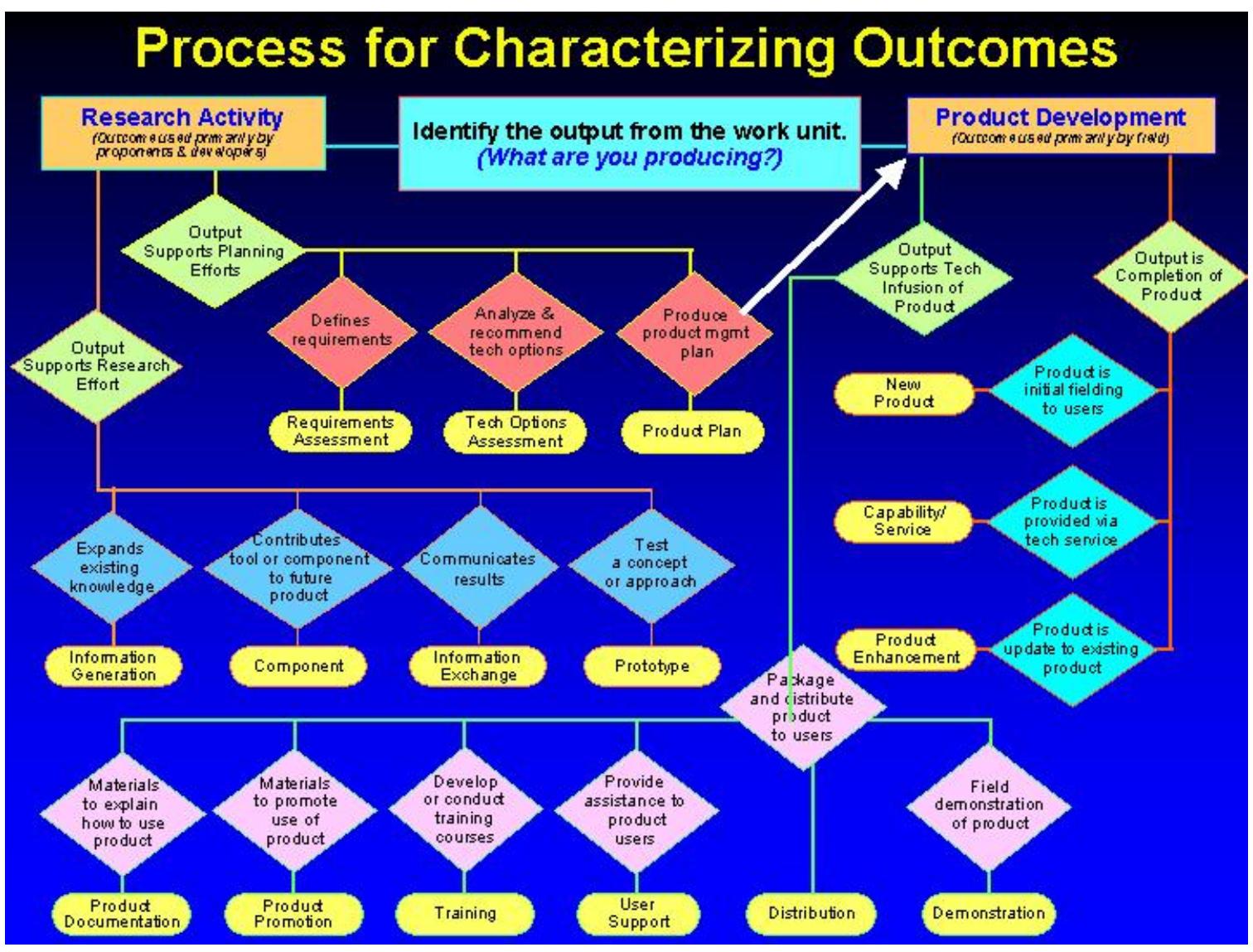

Figure 2. Guidance for further classification of research results and products.

\section{Outcomes for Users/Consumers (Products)}

Product "outcomes" are developed for end users or consumers at Army installations, engineer units, and/or Districts and Divisions, and non-DOD consumers. Consumers can actually "touch and feel" a product. In a true commercial sense, a product would be a "shrink wrapped-like" capability provided to the consumer that is implemented to support their daily operations. A product could be software, hardware, or some innovative procedure that provides the consumer with a new capability to support his or her daily operations. The user should be able to implement a product with minimum hands-on assistance by the technology developers.

Some outcomes would be provided as a technology service to users on a reimbursable basis via the ERDC or other technical centers within the Army or industry. The outcomes for users/consumers, defined below, also include the types of activities necessary to effectively transfer the product to the field. These 
product transition activities will support the infusion of the product or product enhancement to the users.

\section{Product Types}

\section{New Product}

A "new product" is exactly what the name implies, a completely new, neverbefore-provided product that would be implemented by the user with minimum assistance from the developers.

\section{Product Enhancement}

A "product enhancement" differs from a refinement to an existing product in that it enhances its capability to users. Product enhancements would include the introduction of a new version of a software program, addition of a GIS module to an existing product, or modification of an existing software program to include a new algorithm or function. A product enhancement differs from a component described under "research results" in that the enhancement is actually used by the field user. The component, by contrast, is embedded in the product, and is not visible to the field user. The enhancement provides additional product capabilities that will improve the ability of the field user to perform their job.

\section{Capability/Service}

The implementation of some outcomes may require specialized expertise or knowledge not commonly found in field offices. It may be more efficient to train a few individuals to provide these specialized services to users on a reimbursable basis. These technology services may be provided via ERDC labs or centers of technical support in designated Army offices or industry. This would differ from a support center for a product or product enhancement in that the user/consumer would actually implement the product with only minor assistance from the support center.

\section{Product Transition}

\section{Product Documentation}

Development of documentation will assist the user in implementing or authorizing the use of a technology product. Typical documentation consists of instructional materials, guide specifications, user manuals, technical manuals, or other types of guidance materials. 


\section{Promotion}

Promotional activities are designed to inform and motivate potential users to procure and implement a technology. These activities will: (1) generate an awareness of the existence of a technology among potential users, (2) provide information on its uses and benefits, and (3) identify procedures and sources of assistance in obtaining the technology and related services. This would include developing fact sheets, brochures, and promotional videos; presentations before users, and writing articles for trade and user publications.

\section{Training}

Instructional materials are developed to help users apply the product technology. This would include self-instructional materials such as start-up guides and user manuals to help the user begin applying the technology on a limited basis. Advanced training may be developed to further the user's knowledge of the more specific applications of the technology. Special training courses may also be developed for different types of users of the same technology. Online learning and remote training via the internet are alternatives to traditional classroom learning.

\section{User Support}

Users will likely have questions or need some type of assistance in implementing a technology. Some organization or individual will need to be readily available to help with technology problems via phone or e-mail, and to provide users with updates or new product information. Chat rooms or online support centers via listservers and groups on the internet are e-commerce business practices that could also be considered.

\section{Packaging/Distribution}

"Packaging/distribution" refers to those activities that prepare and deliver the technology to the user. Packaging refers to how the technology will be assembled for distribution to the user. Distribution refers to the logistics of getting a technology from a provider of the technology to a user. The Internet has now become a major medium to distribute software and software documentation. 


\section{Example Preliminary Research Outcome Analysis for RSM}

RSM research outcomes were input into a spreadsheet framework and classified into categories (described above). The objective of the outcome analysis was to verify that research program outcomes fit into definitions for the different types of outcomes and the purpose for which they would be used; to develop a prototype database for reporting to managers and others basic information about the program outcomes; and to assist in technology transfer plan development for product lines.

To accomplish this classification effort, RSM research outcomes (termed "milestones" in PROMIS) were extracted from PROMIS PPDS reports and input into a spreadsheet framework. All milestones listed for individual work units within the program were considered as outcomes. Available milestone information, including the description and scheduled completion date were input into an Excel spreadsheet. These milestone "outcomes" were then identified as specific types such as "Technical Report" or "Numerical Model"; designated either a research result or product; and then further subcategorized by purpose to establish the reasons for which they would be used.

Once the outcomes were categorized in this manner, a simple analysis was conducted to provide an overview of the outcome database. Totals of research results and products were calculated by purpose, Work Unit, and milestone type (Tables 9, 10, 11). Also, all publication types were separated from the milestone type list and consolidated in Table 12 .

The process to categorize program outcomes from the PPDS reports was based on interpretations from milestone lists and "Approach" descriptions. All parts of the PPDS reports were thoroughly reviewed to interpret the tasks from other sections in the documentation and place the tasks/products in the appropriate outcome categories and purpose. Reviews of the PPDS reports revealed that few, if any, tasks were defined in the Primary Task/Product list. In many of the RSM work units, the list of primary tasks/products included only publications, which were all indicated as products in PROMIS. In cases where some tasks were listed as Primary Tasks, other obvious tasks were omitted. Additionally, the documentation did not define who would receive the outcomes, and were not organized in terms of life cycle phases (planning, development, implementation, technology transfer). Therefore, parts of this analysis were subject to interpretation. Interpretations proved difficult because of inconsistent and sometimes incomplete organization and development of the Primary Tasks/Products section. 
Table 9. RSM outcomes from documentation.

\begin{tabular}{|c|c|c|}
\hline & Purpose & Total* \\
\hline \multirow{5}{*}{ 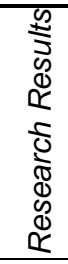 } & Component & 17 \\
\hline & Information Exchange & 56 \\
\hline & Knowledge Generation & 23 \\
\hline & Process Milestone & 9 \\
\hline & Total & 105 \\
\hline \multirow{6}{*}{$\begin{array}{l}\frac{n}{U} \\
\frac{0}{0} \\
\frac{0}{2}\end{array}$} & New Product & 2 \\
\hline & Packaging/Distribution & 2 \\
\hline & Product Documentation & 17 \\
\hline & Product Enhancement & 9 \\
\hline & Product Promotion & 9 \\
\hline & Total & 39 \\
\hline \multicolumn{3}{|c|}{${ }^{\star}$ Total no. of outcomes (Research Results + Products $)=144$} \\
\hline
\end{tabular}

Table 10. RSM outcomes by work units.

\begin{tabular}{|c|c|c|c|c|}
\hline Work Unit & Work Unit Title & $\begin{array}{l}\text { Research } \\
\text { Results }\end{array}$ & Products & Total \\
\hline A1 & Geomorphic response of regional sediment systems & 9 & 0 & 9 \\
\hline A3 & Sand transport during high energy events & 6 & 0 & 6 \\
\hline A4 & Mixing and deformation of alluvial bed surfaces & 4 & 4 & 8 \\
\hline A5 & $\begin{array}{l}\text { Spatial and temporal transport processes in system } \\
\text { context }\end{array}$ & 2 & 2 & 4 \\
\hline A6 & $\begin{array}{l}\text { Freeze-thaw effects on soil and bank erosion and } \\
\text { stability }\end{array}$ & 4 & 3 & 7 \\
\hline A7 & Effects of organics on fine sediment beds & 8 & 0 & 8 \\
\hline B1 & Regional morphology model & 6 & 0 & 6 \\
\hline $\mathrm{B} 2$ & Overland flow, transport, and morphology model & 3 & 5 & 8 \\
\hline B3 & Multi-dimensional sediment model & 1 & 8 & 9 \\
\hline C1 & Integration of engineered solutions & 8 & 0 & 8 \\
\hline $\mathrm{C} 2$ & Measuring and monitoring at large scales & 7 & 0 & 7 \\
\hline C3 & Measuring and monitoring at local scales & 7 & 7 & 14 \\
\hline C4 & Morphologic response test bed database & 9 & 1 & 10 \\
\hline D1 & Database tools for data storage and mining & 8 & 2 & 10 \\
\hline D2 & Multi-level analysis framework & 6 & 1 & 7 \\
\hline D3 & $\begin{array}{l}\text { Graphical user environment to support multi- } \\
\text { dimensional sediment models }\end{array}$ & 3 & 1 & 4 \\
\hline $\mathrm{E} 1$ & Product life cycle planning & 9 & 0 & 9 \\
\hline E2 & Technology transfer services & 5 & 5 & 10 \\
\hline Totals & & 105 & 39 & 144 \\
\hline
\end{tabular}


Table 11. RSM outcomes by milestone type.

\begin{tabular}{|c|c|c|c|}
\hline \multicolumn{2}{|l|}{ Research Results } & \multicolumn{2}{|l|}{ Products } \\
\hline Category* & Total & Category* & Total \\
\hline Algorithm & 3 & Briefing Materials & 1 \\
\hline Algorithm Application & 1 & Brochure & 1 \\
\hline Algorithm Testing & 1 & Data Warehouse & 1 \\
\hline Analysis & 11 & Database & 1 \\
\hline Catalog & 1 & Engineering Manual (EM) & 2 \\
\hline Conference/Workshop Paper & 2 & Exhibit & 1 \\
\hline Database & 3 & Information Update & 2 \\
\hline Database Design & 1 & Interagency Guidelines & 1 \\
\hline Equations & 1 & Journal Paper (JP) & 5 \\
\hline Framework revision & 1 & Model & 4 \\
\hline Guidelines & 1 & Model Revision & 3 \\
\hline Information Update & 1 & Model Testing & 1 \\
\hline Interface & 1 & Newsletter & 1 \\
\hline Journal Paper (JP) & 9 & Technical Note (TN) & 2 \\
\hline Metrics & 1 & Technical Report (TR) & 6 \\
\hline Model (Framework) & 1 & TR Sections & 1 \\
\hline Model (Conceptual) & 4 & User's Manual & 2 \\
\hline Plan & 2 & Website & 2 \\
\hline Security & 1 & Total & 39 \\
\hline Site Selection & 1 & \multicolumn{2}{|c|}{${ }^{*}$ Total number of categories $=18$} \\
\hline Team & 4 & & \\
\hline Template & 1 & & \\
\hline Technical Note (TN) & 32 & & \\
\hline Tool & 1 & & \\
\hline Tool Adaptation & 1 & & \\
\hline Tool Design & 11 & & \\
\hline Technical Report (TR) & 1 & & \\
\hline Workshop & 8 & & \\
\hline Total & 105 & & \\
\hline \multicolumn{2}{|c|}{ * Total number of categories $=28$} & & \\
\hline
\end{tabular}


Table 12. RSM publication outcomes.

\begin{tabular}{|l|c|c|c|}
\hline Publications & Research Results & Products & Total \\
\hline Engineering Manual (EM) & 0 & 2 & 2 \\
\hline Journal Paper (JP) & 9 & 5 & 14 \\
\hline Technical Note (TN) & 32 & 2 & 34 \\
\hline Technical Report (TR) & 1 & 6 & 7 \\
\hline Technical Report sections & 0 & 1 & 1 \\
\hline User's Manual & 2 & 2 & 4 \\
\hline Conference/Workshop Paper & 2 & 0 & 2 \\
\hline Total & $\mathbf{4 4}$ & $\mathbf{1 8}$ & $\mathbf{6 4}$ \\
\hline $\begin{array}{l}\text { Note: Publications constitute approximately 44 \% of all RSM Outcomes, and 44 } \\
\text { and 46\% of Deliverables and Products, respectively }\end{array}$ \\
\hline
\end{tabular}

The task/product development areas in the RSM Program documentation varied because Principal Investigators (PIs) had insufficient, incomplete, or no corporate guidance related to research outcomes (milestone development) definitions, life cycle phases. PIs are the primary developers of program documentation, and typically prepare the documentation using past experience, such as listing only publications as products

Despite the difficulties in locating the appropriate milestones and in interpretation, the preliminary outcome analysis resulted in verifying that research program outcomes do fit into the business categories and purposes and provided basic information that proved valuable to the program manager. Suggestions to obtain more accurate information about research program outcomes include:

- Providing PIs with guidance or templates for developing clear definitions of research program outcomes such as those provided in this report. Figure 2, which shows an outline that uses these business definitions, illustrates a decisionmaking model to help PIs develop their research outcomes in the context of life cycle engineering.

- Revise PROMIS documentation to reflect new outcome categories and purposes

- Develop a reporting system within PROMIS using the outcome analysis framework.

Benefits gained from analyzing the research program include:

- providing RSM proponents and users with overall program results in an understandable and uniform format (tables and charts)

- providing RSM managers with program outcomes to improve decision making at the program and work unit levels

- determining gaps in the life cycle process (i.e., product without supporting documentation or technology transfer mechanisms). 


\section{Relationships Between Outcomes}

One of the benefits of the Product Life Cycle Planning approach is to identify and plan for the relationships between outcome types. Major product or capability/service outcomes may involve voluminous information generation, information exchange, and component and prototype outcomes-all necessary work that builds towards a desired product outcome. The product outcome is then followed by numerous efforts (technology validation, documentation, and implementation planning) required for successful technology infusion.

Communicating and examining these outcome relationships is a critical step in the Product Life Cycle Planning approach. Graphical and narrative views of outcome relationships provide the Project Delivery Team ${ }^{*}$ with a context to look across the life cycle process and ensure that all necessary transitions are identified, planned, scheduled, and resourced. These outcome relationship views also provide an essential form for communicating plans to stakeholders in the process.

Figure 3 shows a "notional" set of outcome relationships in the RSM program. This conceptual framework for outcome relationships is not drawn from actual data from RSM efforts-but is conceptually close to outcome relationships of various efforts in the RSM program. Note that, in this figure, several different efforts build towards a product outcome that will be transitioned to field users. Steps in this notional diagram are sequential. Outcomes from one effort generally contribute to and support a subsequent effort.

However, Figure 3, which provides a second or contrasting example of outcome relationships, shows a product that is already fielded. In this illustration, the outcomes of research and technology development efforts are adding new features and functions to this product over time.

\footnotetext{
*Within Life Cycle Planning, this team may be called the "Product Development Team," which refers to a special type of Project Delivery Team.
} 


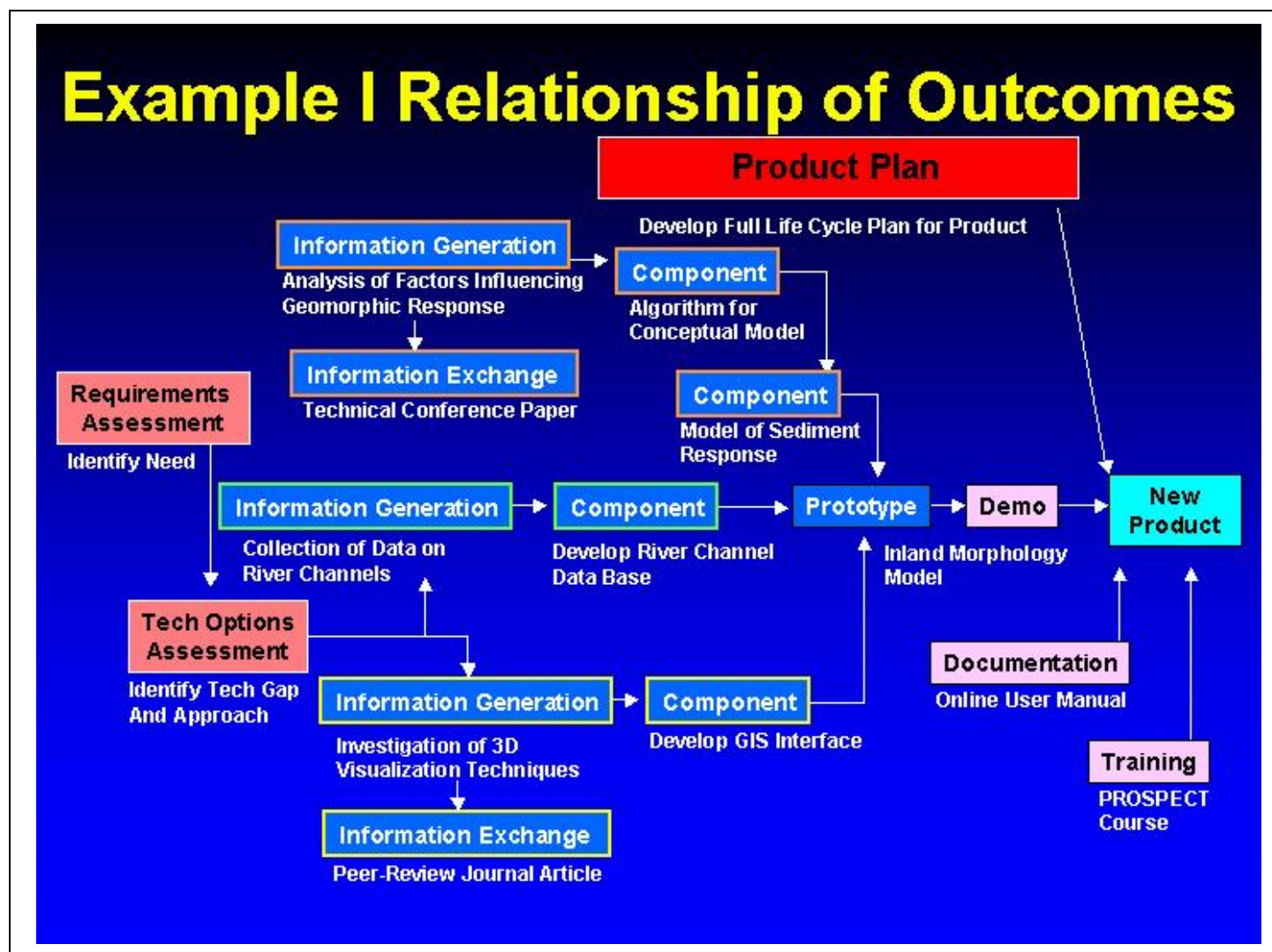

\section{Example II Relationship of Outcomes}

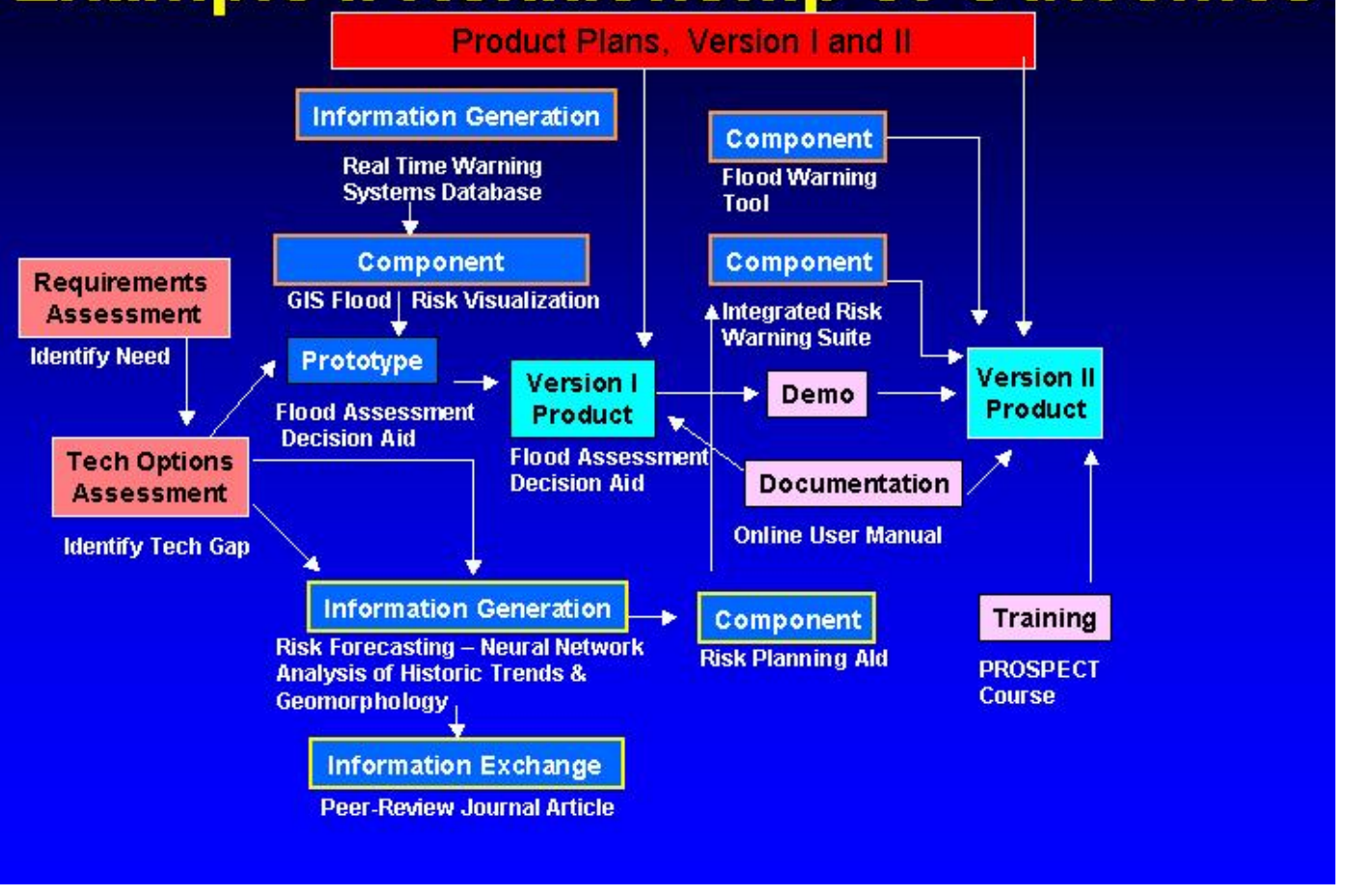

Figure 3. Example relationships of outcomes. 


\section{Publications Product Categories}

\section{Introduction}

The RSM Program will target its publications to two principal audiences: the research and user communities. There are several venues for publications resulting from research in the RSM Program: official USACE publications, ERDC publications, journal publications, conference publications, and miscellaneous publications. Each type of publication is described in greater detail below.

\section{USACE Publications}

The principal audience for USACE Publications is our primary user community, the Corps Districts and Divisions. USACE publication categories include: (1) Army Pamphlets, (2) Army Regulations (3) Army Technical Manuals, (4) Engineer Circulars, (5) Engineer Design Guides, (6) Engineer Manuals, (7) Engineer Pamphlets, (8) Engineer Regulations, (9) Engineer Technical Letters, and (10) Miscellaneous Publications. The RSM Research Program will primarily author the following formal Corps-level categories of publications:

- Engineer Manuals (EM)

- Engineer Pamphlets (EP)

- Engineer Technical Letters (ETL)

- Technical Instructions (TI).

Engineer Publications are posted to the World Wide Web and made accessible through URL:

http://www.hnd.usace.army.mil/techinfo/engpubs.htm

\section{Engineer Manuals (EM)}

An Engineer Manual contains technical guidance and directive/non-directive instruction criteria of a continuing nature concerned primary with engineering and design type projects. For this reason, most EMS are in the 1110 (Engineering and Design) series. Manuals may also include (as appendixes) additional documents such as engineer and technical instructions in which a division chief of the proponent office has the authority to approve. Manuals may not be supplemented. 


\section{Engineer Pamphlets (EP)}

An Engineer Pamphlet may be one of two EP types, standard (or procedural) and informational. A standard EP contains functional or procedural information, instructional guidance needed to implement programs or systems directed in regulations. Procedural pamphlets may include the appropriate additional documents (as appendices). Informational pamphlets are nonpolicy publications that are designed for information only. They consist of booklets, leaflets, and/or folders on various information, recruitment literature, historical studies, and reference texts. The format varies. It is dictated at the proponent's discretion, depending on the type of information it contains. Pamphlets may not be supplemented.

\section{Engineer Technical Letters (ETL)}

An Engineer Technical Letter contains "advance" information on design, engineering and construction projects. ETLs are considered intermediary publications that will eventually be republished in more permanent media. (They will remain active for no more than 5 years from the date of issuance.) The expiration date will be positioned immediately above the series title, and will reflect the last day of a quarter. If, after 5 years, the guidance of a technical letter is still valid, it must be republished as a manual. Technical letters cannot be used to replace regulations or circulars. Technical letters may not be supplemented.

\section{Technical Instructions (TI)}

Technical Instructions are documents used to rapidly provide technical instructions to design offices. TIs provide design and construction criteria, and apply to all U.S. Army Corps of Engineers (USACE) commands having military construction responsibilities; they are essential communications between policy-making elements and execution elements within each of the various technical disciplines. TIs are "living documents" that are periodically reviewed, updated, and made available to users as part of the Headquarters, U.S. Army Corps of Engineers (HQUSACE) responsibility for technical criteria and policy for new military construction. CEMP-ET is responsible for administration of the TI system. Technical content of the TI is the responsibility of the HQUSACE element of the discipline involved. 


\section{ERDC Publications}

The Engineer Research and Development Center (ERDC) regulation 25-30-1, "ERDC Technical Publishing and Printing" (1 December 1999) defines eight categories of official (numbered) ERDC reports: (1) Technical Report, (2) Technical Note, (3) Miscellaneous Paper, (4) Contract Report, (5) Letter Report, (6) Special Report, (7) Monograph, and (8) Brochure. The RSM Program will primarily produce publications in three of these report series, and in one additional (proposed) category:

- Technical Reports (TRs)

- Technical Notes (TNs)

- Miscellaneous Papers (MPs)

- Special Reports (SRs)

- Fact Sheets.

Each publication type has a corresponding electronic Microsoft ${ }^{\circledR}$ Word template with predefined design, page layout, and electronic styles. Authors may use these electronic templates to compose publications in draft form. Authored manuscripts not formatted to publication specifications will be reformatted to meet these standards before final publication. ERDC publication templates are posted to the ERDC Intranet and are accessible through URL:

$\underline{\text { https://iwww.cecer.army.mil/KD/ }}$

The RSM program will target its publications to two principal audiences: the research and user communities. For example, TRs and SRs (by definition, longer publications) that focus on technical information and results will be aimed at the research community. TRs and SRs that focus on documentation and other user issues should be written to satisfy the more general (less technical) user audience. TNs and Fact Sheets (shorter publications) will be written to the more general "user" community. Definitions of each publication series follow.

\section{Technical Reports}

The TR series is the normal vehicle for reporting the detailed processes and results of research projects, i.e., to document sponsored research and development that has been completed or terminated. Technical Reports have specific content requirements for Chapter 1 content, and must also include a formal "Conclusion" chapter. 
A TR Chapter 1 contains these sections:

1. Background (required). The Background should include a problem statement, explain the need for the subject research, and describe its relevance to the Army.

2. Objective(s) (required). The Objectives must include a clear statement of the objective(s) of the research, which may (if the report focuses on a stage of work) be stated as "overall" and "specific" objectives.

3. Approach (required). The Approach delineates the actual steps taken to complete the current research.

4. Scope (not required). The Scope section describes research or application constraints. Researchers may use this section to ensure that the results of their work should not be over- (or under-) generalized, or that (for example) users understand specific preliminary hardware or software requirements of software products.

5. Mode of Technology Transfer (required in "direct-funded" research). The Mode of Technology Transfer (T2) section specifies how the results of the work will be transferred "to the field" (how it will be put in the hands of actual end users) through product distribution, training, secondary publication, or by its contribution to future planned research.

\section{Technical Notes}

Technical notes may contain the same information as a TR, but are shorter and more focused, generally not longer than 10 to 12 pages. Technical notes focus more of research results and less on the research process, but may also include synopses of projects, interim reports describing the early phases of a project (i.e., before there are enough results for a technical report), and spin-off results of a research project (i.e., interesting results that should be reported, but that are not significant enough for a TR).

The RSM Research Program will be producing a series of TNs designed for rapid transmission of technology to the user community. RSM TNs will generally be 2to 10-page notes that identify problem areas and provide techniques or data for solutions that will:

- clarify and call attention to relevant methodology and procedures

- suggest new, improved, or expanded methods used in the solution of RSM problems

- advise of procedures undergoing revision and identify problem areas

- disseminate information on sources of data and unique design procedures developed for specific problems

- promote discussion and an exchange of procedures used in Corps offices. 


\section{Miscellaneous Papers}

This category is for journal articles, conference papers, book chapters, or other shorter works that are published outside of ERDC. The purpose of the category is to track these publications and to ensure that the ERDC and Corps libraries get copies. Miscellaneous publications will address both the research community and the user community.

\section{Conference Publications}

Conference publications will address both the research community and the user community. Conferences are a valuable tool for information exchanges with end users as well as researchers from outside ERDC. Collaborations arising from relationships formed at conferences have often enhanced ERDC research and development. Research results published in peer-reviewed conference proceedings are important in the development of legally defensible engineering theories and practices.

\section{Journal Publications}

Journal papers are refereed publications in journals of professional or technical societies, and as such, address both the research and the user communities. Publication of journal papers is an important factor in providing wide public dissemination of research and development results. Journal papers provide an archival record of research important in the development of legally defensible engineering theories and practices.

\section{Special Report}

Special reports are those that do not fit well elsewhere, but should be included in a numbered series to track these publications and to ensure that the library gets copies. Special reports will address both the research community and the user community. Special reports may include conference proceedings and abstracts, ADP reports, instruction reports, reports that primarily present data, computer program listings, and literature reviews or bibliographies.

\section{Fact Sheets}

Fact Sheets are short (no more than two sides) informational write-ups, written to a general audience, and intended to stimulate interest in a product, facility, capability or service, or area of research. Fact sheets should always guide the reader to the actual "hands-on" product, to an actual facility location, to web 
sites, documentation, training, and/or to laboratory points of contact who can provide further information on the described topic.

\section{Conclusion}

The publications series described here can meet a broad range of reporting, documentation, and marketing purposes. A given project may use a single publication type to meet its reporting needs. On the other hand, each of the four publications series may be seen as complementary, rather than exclusive categories. An individual project or work unit may produce more than one type of publication. A Technical Report may, for example, be accompanied by a companion Technical Note or Fact Sheet describing the same area of research as a way of meeting interim reporting requirements, as a way of addressing a wider audience, or as a way of meeting the dual needs of technical documentation and product marketing. All unclassified ERDC publications are posted to the World Wide Web and made accessible through URL:

http://libweb.wes.army.mil/index.htm 


\section{Technology Transfer Planning}

\section{Introduction}

Technology transfer has long been a challenge for the U.S. Army Corps of Engineers (USACE) and its Research and Development (R\&D) community. The R\&D community has developed several technologies and products that have been transferred into use by only a handful of users. Some other technologies have received widespread use. The USACE Engineer Research and Development Center (ERDC) needs to improve its ability to work with technology proponents and users to ensure technology transfer occurs. This chapter outlines some concepts associated with successful technology transfer and proposes a planning framework for increasing the likelihood of future success in the Army.

\section{Lessons From Commercial Approaches}

Unlike the Government sector, successful commercial businesses tend to be very successful at marketing or transferring their technology products into use. The American Marketing Association defines marketing as the "process of planning and executing the conception, pricing, promotion, and distribution of goods, services, and ideas to create exchanges with target groups that satisfy end user and organizational objectives." This is basically what technology transfer is all about - putting technologies in the hands of users for their benefit. By doing so efficiently, USACE and ERDC will meets its organizational goals of improving its end users productivity or well being via technology development and delivery.

Large commercial businesses such as Microsoft, Intel, and Ford Motor Company have a well-established process for marketing or transferring their technologies and products to users. Businesses such as these: (1) conduct market research to identify consumer needs and preferences; (2) they develop products to meet those requirements; and then (3) apply proven methodologies to effectively promote, package, price, and distribute their products to consumers. As the lifeblood of a commercial business is revenue generated by the sale of products, it dedicates the necessary resources and hires trained personnel to effectively plan and execute the marketing of its products. 
The Army and USACE attempts to define user technology needs through the Army's Research, Development, Testing, and Evaluation (RDT\&E) program. RDT\&E funding lines, which provide a resource base for product development. These funding lines are limited to basic research and applied research activities and are not available for use in demonstration or technology transfer activities. These activities could be improved with more effective involvement of both headquarters level technology proponents and the ultimate users of the technologies under development.

Currently, the USACE R\&D community has varying approaches to the third marketing activity - the promotion, packaging, and distribution of its technologies. In some research areas, technical assistance programs such as the Dredging Operations Technical Support (DOTS), Water Operations Technical Support (WOTS), and Wetlands Regulatory Assistance Program (WRAP) programs do provide some support, particularly in distribution of technologies. In other research areas, no promotion, packaging, and distribution is supported. Nor does the USACE R\&D community currently systematically plan for the transfer of its technology. This planning function should be done by proponent organizations that would sponsor and ensure funding is available to support the use of the technology among its constituent users. The R\&D community should support this planning effort. The Internet and e-commerce principles have become a major tool to support planning efforts to infuse technology.

Another key to successful technology transfer that has been overlooked by the R\&D community and proponents alike is the challenge of getting an organization ready to implement a new technology. Much has been written in organizational literature about managing change. Implementing new technology in an organization must be a well organized and planned effort complete with proper management emphasis, resourcing, training, and revised business practices to acquire and implement a new technology. Proponents are in a key role to ensure the changes associated with technology implementation are addressed in any technology transfer plan.

Successful technology transfer requires strong proponency to ensure the technology is developed to effectively support existing or planned business practices, the implementation is properly planned and executed, and organizations are properly prepared to implement a technology. Adequate resources must be available throughout the life cycle of this technology development and implementation effort. 


\section{Technology Development}

\section{Identification of Future Operational Capabilities (FOC) and Requirements}

Success at technology transfer is much easier for a technology that meets a true need of the user community. Successful businesses focus research and development investment on technologies that offer the greatest likelihood of commercial success. Identifying future technology needs requires the active participation of end users.

Within the Army, the ERDC has two major categories of users-proponents and users. Each will provide their unique perspectives in defining future technology needs and must be involved in the identification of future technology needs. Proponents typically provide the long-range vision for how the Army needs to operate in the future. Proponents have the ultimate responsibility for ensuring the technology exists to support that future operational vision and to plan for the transfer of the technology into daily use. Users provide valuable perspective on existing or future business practices and how technology would impact those practices.

Future Operational Capabilities (FOCs) are intended to identify future business practices and the associated technology required to support those practices. Both proponents and users need to participate in the development and validation of FOCs. Once FOCs have been identified, Army technology proponents need to work closely with the R\&D community throughout the development and transition effort to ensure success.

\section{User Input to Technology Development}

Technologies must be developed to be compatible with and support existing or planned existing business practices. The R\&D community must be closely aligned with the actual users of the technology and collect input from them throughout the development process. Proponents may be too far removed from the daily business operations to understand the impact of technology on daily operations. User groups consisting of representatives of a broad spectrum of users should be formally established to provide such input. Formal user groups should also be employed for technology opportunities. In this case, innovative technologies often appear that will shape existing or create future business practices in ways not currently recognized. Proponents and users need to work with the R\&D community to define these business practices in light of these technology opportunities. 


\section{Demonstration and Operational Testing}

The field demonstration is a key element in the overall transfer of the technology. The demonstration is the first attempt to show the effectiveness of the technology before Army-wide users. The focus of the demonstration should be on how the user implements and benefits from the technology. Whether or not a technology works should be proven earlier via bench tests or field tests. The demonstration should identify operational problems facing users resulting from its implementation and use that will inhibit technology infusion efforts. The demonstration should be conducted without heavy involvement of R\&D personnel.

Information from the demonstration is critical to the technology infusion planning effort described next. The demonstration provides an opportunity to identify the effectiveness of documentation and instructional materials and what type of technical support will be necessary. A successful demonstration will produce information on cost of implementation and savings achieved from its use that should be highlighted in promotional efforts.

\section{User Validation}

As a result of the demonstration process, users and proponents need to validate the benefits and the need for implementing the technology among the various users in the Army. The operational validation and results of the demonstration become proof of the usefulness of the technology and the need to move forward with implementation. Proponents need to step up and visibly show their support for implementation before the broader user community.

\section{Technology Infusion Planning}

Technology infusion plans as defined here are a series of activities that must be implemented to deliver a technology to potential users. Consequently the implementation of these activities must be planned, scheduled, and assigned to individuals for completion. These planning activities consist of: documentation; packaging, pricing and distribution; promotion; training; technology support; and promotion. Without each of these activities in place, it will be difficult to successfully transfer technology to the users. Figure 4 shows a sample technology transfer "thumbnail" plan. This thumbnail plan incorporates many of the issues involved in technology transfer planning discussed here. Such a thumbnail plan should be developed during the technology development stage early in the product life cycle process to identify potential technology transfer issues. 
Technology Transfer “Thumbnail”

Research Program: Regional Sediment Management

Product:

Work Unit Number:

Thumbnail Date:

Product Introduction Date:

ERDC Project Manager:

HQ Proponent:

Product Description:

Infusion Plan

Documentation:

Funding: Source: $\quad$ Completion Date: POC:

Packaging/Distribution:

Funding: Source: Completion Date: POC:

Promotion:

Funding: Source: Completion Date POC:

Training:

Funding: Source: Completion Date POC:

User Support:

Funding: Source: Completion Date POC:

\section{Implementation Issues/Strategies}

\section{Organization Change}

\section{Business Processes}

$\underline{\text { Resource Allocation }}$

\section{$\underline{\text { IT Infrastructure }}$}

Technology Upgrade \& Maintenance

Figure 4. RSM technology transfer "thumbnail." 
Responsibility for implementing the various activities within the implementation mix will most likely fall upon many different people and organizations. Army technology proponents responsible for implementing the overall technology transfer plan must ensure that individuals with responsibilities understand their roles and the schedule in which the duties must be performed. Proponents must also ensure that adequate financial and personnel resources are available to support the activities of the technology infusion plans.

Funds to support the oversight and management of technology transfer activities need to be identified and budgeted for. Some of these costs may be paid for out of normal operating expenses for organizations involved in technology transfer planning. Technology transfer planning costs could be supplemented by charging end users a price for acquiring the technology. Additional costs will be born by organizations implementing the technology. Technology transfer plans should identify estimates for both types of costs.

\section{Documentation}

Documentation consists of instructional materials to be included with the technology and guidance documents that authorize the use of the technology. Formal Army guidance documents such as guide specifications or technical manuals are critical to the acceptance of the technology by the user. While not usually part of the technology package that is distributed to users, it nevertheless supports the use of the technology by the field. In some cases-such as new proceduresthese documents may be the only way such technologies are delivered to users. Revisions to formal Army technical documents to include the technology typically can take years to complete. Interim guidance can be provided through Engineering Technical Letters or letters of authorizations accompanied by technical information such as user guides. These documents and later updates can be made available via the Internet.

\section{Packaging, Pricing, and Distribution}

Packaging refers to how the technology will be assembled for distribution and use by the user. Packaging includes instructional materials to be included with the technology. Technology transfer costs could be supplemented by charging end users a price for acquiring the technology. Distribution refers to the logistics

of getting a technology from a provider of the technology to a user. Technologies are typically shipped through the mail or freight services, or delivered personally. A single distribution point is recommended to avoid confusion among potential users. Distribution centers-whether they be government or commer- 
cial—need to be staffed adequately to ensure responsiveness to user requests. The Internet has now become a major medium to distribute software and documentation supporting its use. Online orders and payments for acquiring technologies is now a common e-business practice.

\section{Training}

Some technologies may be more complicated to learn than others. Instructional material included with the technology may only serve to get the user started on applying the technology on a limited basis. Advanced training may need to be developed to further the user's knowledge of the more specific applications of the technology. Special training courses may also need to be developed for different types of users of the same technology. For example, individuals responsible for designing a heating control system into a building would need different training than those responsible for operating the controls later on. The scheduling of training should coincide with goals of how quickly the technology should be adopted by users. Online learning and remote training via the Internet is now a proven alternative to traditional classroom learning.

\section{Technology Support}

Users will inevitably have questions or need some type of assistance in implementing a technology. Some organization or individual must be readily available to assist users. The staffing of this central source of assistance and the services it provides will vary depending on the nature of the technology and the expected need for assistance. Typically, such a center should be able to assist users with questions over the phone, conduct onsite visits to assist with technology problems, and provide them with updates or new information on the product. Chat rooms or online support centers via the Internet are e-commerce business practices that should be applied in conjunction with traditional methods.

\section{Promotion}

Promotion activities are designed to inform and motivate potential users to procure and implement a technology. Promotion activities should generate an awareness of the existence of a new technology among potential users, provide information on its uses and benefits, and identify procedures and sources of assistance for obtaining the technology and related services. The ultimate goal is to provide information to assist the user in making a decision to acquire the technology. The timing of promotion activities typically should not precede the establishment of mechanisms to distribute and support the technology. A critical component of promotional planning is defining the target audience for the 
promotional activities. Different promotional efforts and messages should be implemented for each of these audiences. Repetitive, quality messages are critical to ensure adequate reach and frequency is achieved among the target end users. The technology proponents and ERDC need to establish a program for sustaining the promotion of available technologies and support services using both Internet communication tools and traditional media.

\section{Preparing the Organization To Adopt a Technology}

The technology infusion environment can be thought of as a complex nexus where organizational culture, business processes, resource allocation and information technology infrastructure co-exist to facilitate or pose barriers to the adaptation of technological innovation. It seems that the readiness of the following four elements are necessary to facilitate a successful technology infusion to the end users:

1. Organization and culture readiness

2. Business process readiness

3. Resource allocation readiness

4. Information technology infrastructure readiness.

Change management concepts and practices should be applied to adequately prepare an organization to implement a new technology. The change management effort should focus on addressing these four barriers to technology infusion.

\section{Organization and Culture Readiness}

The first critical element is Organizational and Cultural Readiness for Technological Innovation. A culture that has inflexible regulations or otherwise encourages risk avoidance can result in severe barriers to technology infusion. New technology that conflicts with widespread cultural values may be rejected. For example, if the general tendency of a culture is that items are disposable, recycling may be not be successful. Fear of liability may encourage conservative approaches and it may be difficult to set up field demonstrations. Successful technology infusion requires methods to overcome such organizational/cultural barriers to be so that the Corps of Engineers and the Army can benefit from daily use of technological innovation.

\section{Business Process Readiness}

The second critical element is Business Process Readiness for Technology Infusion. If a new technology is delivered when old business processes inhibit or in- 
terfere with the implementation of new technology, it will be impossible to gain the benefits of this technology infusion. This technology will be stored on a shelf rather than used. A number of technologies developed as a result of the Corps of Engineers R\&D program could be described this way. For example, when a module of Engineered Management System (EMS) is delivered, the business process is not changed to obtain the maximum benefit of the EMS, but it is imposed onto the end user to use it within old business process constraints. This may not encourage people who could potentially benefit from this because it is difficult to fit the new technology into the old business process. Army recommends PAVER as an option, but Air Force is using the PAVER differently because the process was changed to require PAVER analysis in requesting airfield maintenance funds. So it is important to consider changing the business process, including the type of training needed, when a new technology/system is delivered to a user community.

\section{Resource Allocation Readiness}

The third critical element is Resource Allocation Readiness for Technological Innovation to help ensure availability of an appropriate amount of dollars to support the life cycle management of a new technology. We read of many cases where new computer systems were not implemented and supported successfully due to financial problem and these systems being dropped as failure. A sound financial plan for the life cycle management of a new technology is necessary to produce successful technology infusion. It is mandatory to have not only a financial plan, but also the commitment of leadership to provide the necessary resources at the time needed, not a few years later. Without actual dollars to support life cycle management of a new technology, any technology infusion cannot be successful. However, it is not clear how to obtain the commitment before the technology is completed for delivery. Even though there is an LCMIS regulation for all information system development, lack of funding for the life cycle seems to be one of the most frequent reasons for not achieving the level of success expected from new technologies. An organization planning to adapt a new technology must perform an analysis that considers the cost of operations and maintenance, cost of system upgrade, and the cost of training users and support personnel.

\section{Information Technology Infrastructure Readiness}

The fourth critical element is Information Technology (IT) Infrastructure Readiness for Technological Innovation. With rapid advances in information technology, a major contributing factor to new infrastructure technology development is information technology. Often new technologies are developed under the as- 
sumption that end-users will have a certain IT infrastructure. Yet many users may not have the correct IT infrastructure to use the new technology when it is ready for delivery, limiting the benefit of this technology to only those with IT infrastructure readiness. Therefore, it is necessary to consider IT infrastructure readiness, as an essential element, when a new technology is being developed and getting ready to be delivered. For example, an IT platform, communication lines, operating systems, and data structure need to be considered together as well as application architecture. 


\section{Conclusions}

The concepts proposed in this report are intended to improve life cycle planning approaches and infusion success from USACE research investments. The authors recommend that the concepts proposed in this report be tested within RSM and other associated research programs (e.g., TOWNS, SMART) and then evaluated, modified and verified before they are adopted by broader USACE research and technology communities of interest. However, these recommended concepts for Product Life Cycle enhancements are intended, eventually, for all of USACE.

Because of this broad scope, the technology life cycle is viewed here from the USACE/Army perspective, with research fitting into this perspective as only one possible course of action that might be considered as a result of a technology requirement or opportunity. Other courses of action might be to simply acquire existing off-the-shelf capabilities, to acquire service support from a provider, or to adopt a capability already in use by another organization/agency.

Viewing research outcomes as a component of the technology life cycle does facilitate connecting research with our USACE processes. Thus, a key to our recommended concepts is linkages to the USACE Project Management Business Process (PMBP), to the Science and Engineering Technology (SET) initiative, and to the emerging USACE Technical Architecture. Our cornerstones of change include the following three major areas:

- use of standard outcome types and transition plans

- teaming for success through the use of PMBP approaches in the product life cycle process

- use (and shaping of) the emerging technical architecture for IT-based product outcomes.

These three approaches, if followed, should greatly improve the infusion success from our research investments, and enhance the linkages between USACE technology plans and research outcomes. 


\section{Bibliography}

Army Regulation 701, Research, Development and Acquisition (15 January 1998), accessible through URL:

http://www.army.mil/usapa/epubs/pdf/r70_1.pdf

DoD Directive 5000.1, The Defense Acquisition System (12 May 2003), accessible through URL: http://www.dtic.mil/whs/directives/corres/html/50001.htm

Headquarters, U.S. Army Corps of Engineers (HQUSACE) Project Management Business Process home page, accessible through URL:

http://www.hq.usace.army.mil/pmbp/

Project Management Business Process (PMBP) Portal, accessible through URL: https://pmbp.usace.army.mil/servlet/page?_pageid=245,247\&_dad=portal30\&_schema=PO $\underline{\text { RTAL30 }}$

Roussel, Philip A., Kamal N. Saad, and Tamara J. Erickson, Third Generation R\&D: Managing the Link to Corporate Strategy (Arthur D. Little, Inc., 1991).

U.S. Army Corps of Engineers, Engineer Regulation \#25-1-2, Information Management, Life Cycle Management of Information Systems (31 August 1999), accessible through URL: http://www.usace.army.mil/inet/usace-docs/eng-regs/er25-1-2/entire.pdf

U.S. Army Corps of Engineers, Regulation 25-1-98, Standard Operating Procedures for U.S. Army Corps of Engineers Data Standardization (May 1998), accessible through URL: http://www.usace.army.mil/ci/dataadmin/pdfs/Datastv1.pdf

U.S. Army Corps of Engineers, Engineer Regulation 5-1-11, Management, U.S. Army Corps of Engineer Business Process (17 August 2001), accessible through URL: http://www.usace.army.mil/inet/usace-docs/eng-regs/er5-1-11/entire.pdf

U.S. Army Engineer Research and Development Center (ERDC) Project Management Business Process (PMBP) Guide: accessible through URL: https://erdcinfo.erdc.usace.army.mil/exec/pmbp/taskforce/Main.htm

U.S. Army TRADOC Regulation 350-70, accessible through URL: http://sill-www.army.mil/fdic/stafffaculty/tr350_70/iv3-intr/IV3INTR.HTM 


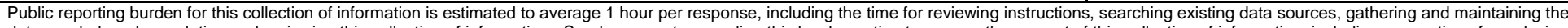

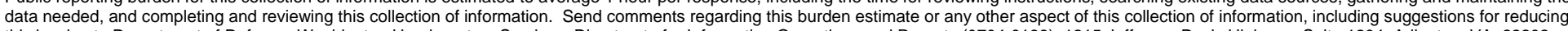

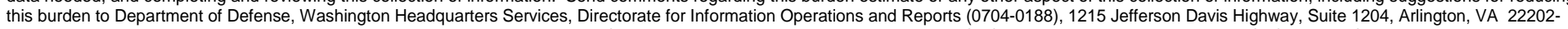

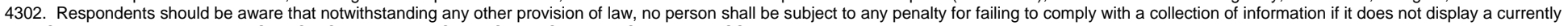
valid OMB control number. PLEASE DO NOT RETURN YOUR FORM TO THE ABOVE ADDRESS.
1. REPORT DATE (DD-MM-YYYY)
2. REPORT TYPE
3. DATES COVERED (From - To)

24-06-2003

Final

\section{TITLE AND SUBTITLE}

Product Life Cycle Planning

5a. CONTRACT NUMBER

5b. GRANT NUMBER

5c. PROGRAM ELEMENT

6. AUTHOR(S)

Jeffrey J. Walaszek, William D. Goran, Cary D. Butler, Kay C. McGuire, Terri L. Prickett,

Kathleen D. White, and William J. Wolfe

\section{5d. PROJECT NUMBER \\ $\mathrm{CW}$}

5e. TASK NUMBER

392

5f. WORK UNIT NUMBER

RSM-E1

\section{PERFORMING ORGANIZATION NAME(S) AND ADDRESS(ES)}

U.S. Army Engineer Research and Development Center (ERDC)

Construction Engineering Research Laboratory (CERL)

PO Box 9005,

Champaign, IL 61826-9005

8. PERFORMING ORGANIZATION REPORT NUMBER

ERDC SR-03-1

9. SPONSORING I MONITORING AGENCY NAME(S) AND ADDRESS(ES)

10. SPONSOR/MONITOR'S ACRONYM(S)

Coastal and Hydraulics Laboratory

3909 Halls Ferry Road

Vicksburg, MS 39180-6199

CEERD-HC-SE

11. SPONSOR/MONITOR'S REPORT NUMBER(S)

\section{DISTRIBUTION I AVAILABILITY STATEMENT}

Approved for public release; distribution is unlimited.

\section{SUPPLEMENTARY NOTES}

Copies are available from the National Technical Information Service, 5285 Port Royal Road, Springfield, VA 22161.

\section{ABSTRACT}

Sediment Management (RSM) refers to the effective use of littoral, estuarine, and riverine sediment resources in an environmentally effective and economical manner. The U.S. Army Corps of Engineers manages lands and waterways across the United States. The Corps' use of RSM concepts will significantly improve the its mission accomplishment. As part of that mission, Corps' engineers and scientists develop new technologies to make management decisions more accurate and efficient. Simultaneously, they evaluate RSM concepts through demonstration projects that highlight and improve sediment management activities. This phase of work was undertaken to: (1) provide guidelines, technical support, and planning approaches for researchers that result in realistic life cycle plans for products emerging from the RSM research program; (2) focus the RSM program community of interest on the planned outcomes of the RSM investment, and the infusion of these outcomes into District operations; (3) identify and resolve barriers to successful technology infusion; (4) develop approaches and metrics for measuring technology infusion success and processes for making post-infusion adjustments to improve this success, (5) facilitate successful technology transfer beyond USACE. The concepts proposed here are intended to improve life cycle planning from USACE research investments.

\section{SUBJECT TERMS}

civil works

technology infusion

life cycle planning technology transfer

\begin{tabular}{|l|l|l|}
\hline \multicolumn{2}{|c|}{ 16. SECURITY CLASSIFICATION OF: } \\
\hline $\begin{array}{c}\text { a. REPORT } \\
\text { Unclassified }\end{array}$ & $\begin{array}{c}\text { b. ABSTRACT } \\
\text { Unclassified }\end{array}$ & $\begin{array}{c}\text { c. THIS PAGE } \\
\text { Unclassified }\end{array}$ \\
\hline
\end{tabular}

\begin{tabular}{|c|c|c|}
$\begin{array}{c}\text { 17. LIMITATION } \\
\text { OF ABSTRACT }\end{array}$ & $\begin{array}{c}\text { 18. NUMBER } \\
\text { OF PAGES }\end{array}$ & $19 a$ \\
SAR & 60 & $19 \mathrm{~b}$ \\
\end{tabular}

\begin{tabular}{l} 
19a. NAME OF RESPONSIBLE PERSON \\
William D. Goran \\
$\begin{array}{l}\text { 19b. TELEPHONE NUMBER (in- } \\
\text { clude area code) } \\
\text { (217) } 373-6735\end{array}$ \\
\hline
\end{tabular}

